\title{
Late Cenozoic bending of the Bolivian Andes: New paleomagnetic and kinematic constraints
}

\author{
Richard Barke, ${ }^{1,2}$ Simon Lamb, ${ }^{1}$ and Conall MacNiocaill ${ }^{1}$ \\ Received 1 March 2006; revised 21 July 2006; accepted 5 September 2006; published 9 January 2007.
}

[1] New paleomagnetic measurements of essentially undeformed Late Cenozoic volcanic rocks in the Bolivian Andes, South America, constrain rigid body rotations about vertical axes during the last 13 Myr on both limbs of the Bolivian orocline in the Eastern Cordillera. Thermal and alternating field demagnetization was carried out on samples from 52 sites in three major volcanic complexes: (1) 13-2 Ma Los Frailes ignimbritic volcanics, outcropping at $\sim 19.5^{\circ} \mathrm{S}$; (2) $9-5$ Ma Morococala ignimbritic volcanics, outcropping at $\sim 18^{\circ} \mathrm{S}$; and (3) $13-5$ Ma shoshonitic to acidic lavas and intrusives, outcropping at $\sim 17.5^{\circ} \mathrm{S}$. Well-defined magnetic components were isolated, which are interpreted to represent the Earth's magnetic field at the time of volcanic activity. The mean magnetic vector for site groupings suggests regional tectonic rotations about vertical axes, with respect to stable South America, of $10^{\circ} \pm 8$ clockwise for the 13-2 Ma Los Frailes volcanic complex $\left(8^{\circ} \pm 9^{\circ}\right.$ clockwise for only the Miocene (13-5 Ma) Los Frailes volcanics), and $1^{\circ} \pm 18^{\circ}$ anticlockwise for the combined 13-5 Ma Morococala and Eucalyptus volcanic complexes. These data are consistent with observed shortening gradients on the eastern margin of the Bolivian Andes, in the sub-Andean zone, suggesting rotation and shortening are synchronous. A joint inversion for both tectonic rotation and the amount of shortening, assuming a linear variation in the amount of rotation along the length of the southern limb of the Bolivian orocline, shows that rotation of the Eastern Cordillera in the last 10-15 Myr, relative to stable South America, varies from zero at the oroclinal hinge, at $\sim 18^{\circ} \mathrm{S}$, to a maximum of $\sim 13.5^{\circ}$ clockwise at $\sim 22^{\circ} \mathrm{S}$, decreasing to zero, south of $23^{\circ} \mathrm{S}$, with an average rotation in the range $5^{\circ}$ to $10^{\circ}$ clockwise. Concomitant with this, shortening in the sub-Andean zone decreases from a maximum of $\sim 86 \mathrm{~km}$ at the oroclinal hinge, to $\sim 47 \mathrm{~km}$ at $22^{\circ} \mathrm{S}$, and then $\sim 33 \mathrm{~km}$ at $23^{\circ} \mathrm{S}$. The lack of evidence for large-scale internal faulting in the Eastern Cordillera since $\sim 9$ Ma suggests either bending of the Eastern Cordillera was accommodated by more distributed small-scale faulting or that relative rotation here mainly occurred prior to $\sim 9 \mathrm{Ma}$. The small average rotation of the Eastern Cordillera, on the southern limb of the orocline, is consistent with only very small rotation $\left(<10^{\circ}\right)$ of the forearc region in northern Chile during the last $\sim 20$ Myr. Rotation of the northern limb is less well constrained, but it is also likely to be small $\left(<5^{\circ}\right)$ and anticlockwise.

Citation: Barke, R., S. Lamb, and C. MacNiocaill (2007), Late Cenozoic bending of the Bolivian Andes: New paleomagnetic and kinematic constraints, J. Geophys. Res., 112, B01101, doi:10.1029/2006JB004372.

\section{Introduction}

[2] The general topographic trends of many mountain belts are markedly sinuous, with pronounced bends. At the largest scale, comparable to the dimensions of the mountain belt itself, these bends define oroclines. For example, there are a number of clear oroclinal bends in the great mountain ranges of Europe and Asia, extending from the Alps to the Middle East and Asia, and also along the Andean mountain chain following the western margin of South America. The

\footnotetext{
${ }^{1}$ Department of Earth Sciences, University of Oxford, Oxford, U.K.

${ }^{2}$ Now at ExxonMobil, Aberdeen, Alberta, Canada.

Copyright 2007 by the American Geophysical Union. 0148-0227/07/2006JB004372\$09.00
}

origin of these oroclines, however, remains an important problem in geology, and it is generally unclear whether they developed mainly during mountain growth, or largely existed prior to the onset of deformation. Paleomagnetic studies have the potential to help solve this problem: If the orocline has formed during deformation, then it is likely to be associated with rigid body rotations about vertical axes, and these should be detected in the paleomagnetism of the rocks. This simple idea is, however, complicated by the fact that the same rotations could be local block rotations, associated with distributed internal deformation without the need for oroclinal bending at all. Whatever the case, at some fundamental level, these rotations place important constraints on the kinematics and dynamics of continental deformation. Oroclinal bending, where it can be unambiguously documented, 


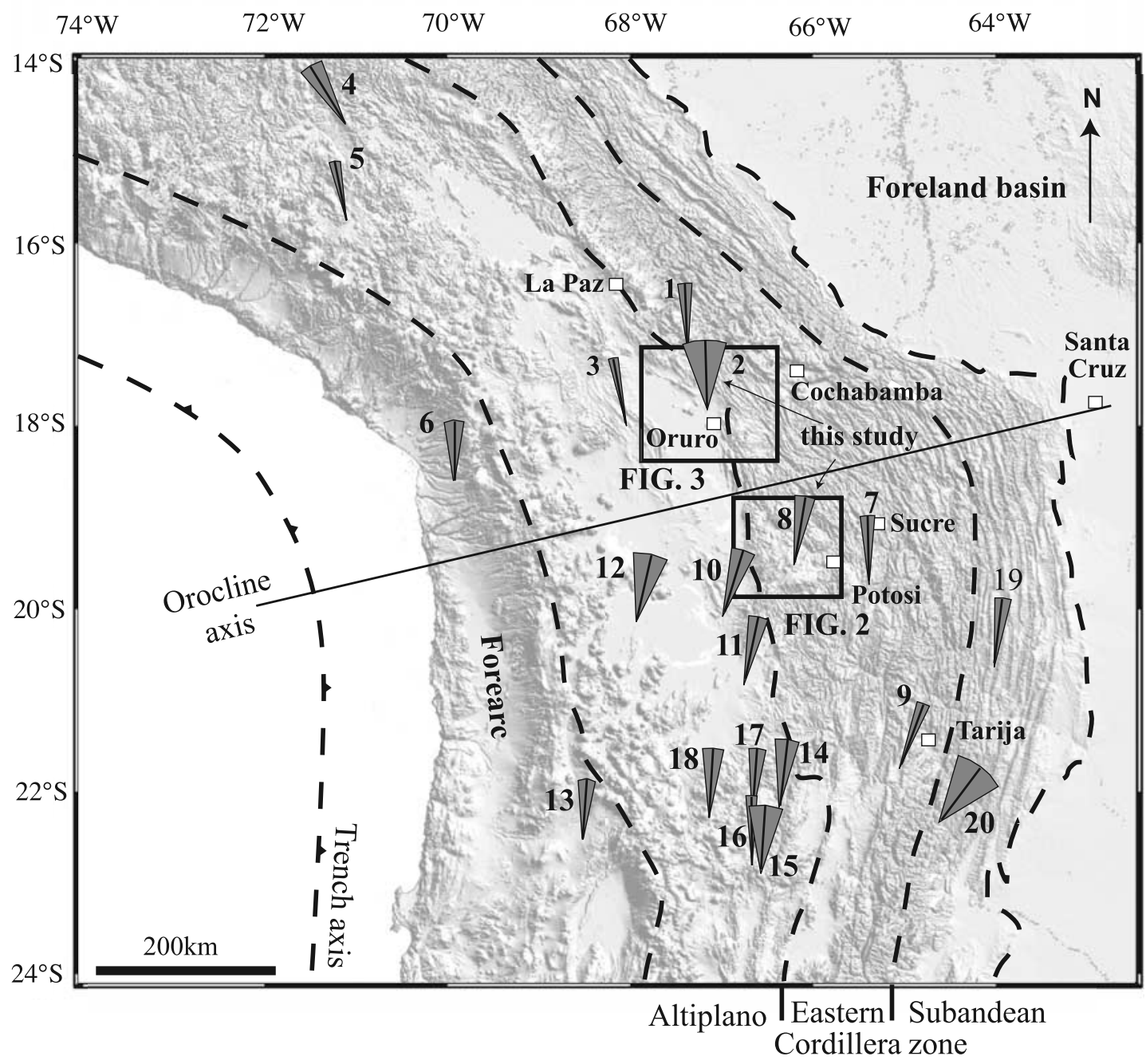

Figure 1. Central Andes, on the western margin of South America, in the vicinity of the hinge of the Bolivian orocline, with shaded relief topography (SRTM, $90 \mathrm{~m}$ digital elevation model) and major Bolivian cities, showing location of study areas (boxes). The oroclinal bend is defined by the swing of the general topographic and structural trends, as well the trench offshore. The study areas consist of the 13-2 Ma Los Frailes volcanic complex (see Figure 2) and 13-5 Ma Morococala and Eucalyptus volcanics (Figure 3), either side of the hinge of the Bolivian orocline. Pie wedges represent the $95 \%$ confidence intervals for paleomagnetically determined Late Cenozoic rotations about vertical axes in this and previous studies, with respect to stable South America (see Table 1, keyed to reference numbers); the mean direction ( $\mathrm{R}$ value) is indicated by the central black line.

reflects spatial variations in the forces that drive continental deformation, the rheology of the lithosphere and the resulting bulk strain [Lamb, 2001b].

\subsection{Bolivian Orocline}

[3] In the central Andes, at the latitudes of northern Chile and Bolivia, around $\sim 18^{\circ} \mathrm{S}$, there is a marked $\sim 45^{\circ}$ swing in the azimuth of the structural and topographic trends. This defines the Bolivian orocline, which forms part of the active plate boundary zone between the Nazca and South American plates. Offshore, in the Peru-Chile trench, the Nazca Plate is being subducted in a roughly ENE direction at $\sim 80 \mathrm{~mm} \mathrm{yr}^{-1}$ (averaged over the last few million years (NUVEL-1A [DeMets et al., 1994]) beneath the western margin of South America. Subduction here has been continuous since at least the Jurassic, and certainly much further back in time as well. Structural, sedimentological and paleontological studies show that the central Andes, as a major structural and topographic feature of South America, have formed since the Eocene [Allmendinger et al., 1997; Jordan et al., 1997; Lamb et al., 1997; Lamb and Hoke, 1997; McQuarrie, 2002].

[4] In the last 25 years, there have been numerous paleomagnetic studies that have attempted to elucidate the origin of the Bolivian orocline (see summary by Lamb [2001a]). Figure 1 and Table 1 show a compilation of published Late Cenozoic rotations about vertical axes for the Andes in southern Peru, Bolivia and northernmost Argentina, relative to stable South America. This reflects a more regional and longer term pattern in the central Andes 
Table 1. Late Cenozoic $(<15 \mathrm{Ma})$ Paleomagnetic Data for the Central Andes ${ }^{\mathrm{a}}$

\begin{tabular}{|c|c|c|c|c|c|c|c|c|c|c|c|c|c|}
\hline Label & Region & Zone $^{\mathrm{b}}$ & $\begin{array}{c}\text { Age, } \\
\mathrm{Ma}\end{array}$ & $\begin{array}{c}\text { Latitude, } \\
{ }^{\circ} \mathrm{S} \\
\end{array}$ & $\begin{array}{c}\text { Longitude, } \\
{ }^{\circ} \mathrm{W}\end{array}$ & $\begin{array}{l}\mathrm{D}^{\mathrm{c}} \\
\mathrm{deg}\end{array}$ & $\begin{array}{l}I^{c}{ }^{\mathrm{c}} \\
\mathrm{deg}\end{array}$ & $\begin{array}{l}\mathrm{a}_{95}{ }^{\mathrm{c}} \\
\text { deg }\end{array}$ & $\begin{array}{l}\mathrm{R}^{\mathrm{d}} \\
\mathrm{deg}\end{array}$ & $\begin{array}{c}\Delta \mathrm{R},{ }^{\mathrm{d}} \\
\mathrm{deg}\end{array}$ & $\begin{array}{l}F_{F}{ }^{d} \\
\text { deg }\end{array}$ & $\begin{array}{c}\Delta \mathrm{F}^{\mathrm{d}} \\
\mathrm{deg}\end{array}$ & Reference \\
\hline \multicolumn{14}{|c|}{ Northern Limb } \\
\hline 1 & Micana & EC & $8-6$ & 17.5 & 67.5 & 355.2 & -25.8 & 5.9 & -2.1 & 5.6 & -11.3 & 5.0 & MacFadden et al. [1990] \\
\hline 2 & Mor-Eucalyptus & EC & $13-5$ & 17.8 & 67.3 & 355.9 & -34.3 & 18.6 & -1.4 & 18.3 & -3.2 & 15.0 & this study \\
\hline 3 & Totora Formation & A & $14-9$ & 17.5 & 68.3 & 347.0 & -22.0 & 3.0 & -10.2 & 3.3 & -15.0 & 2.9 & Roperch et al. [1999] \\
\hline 4 & Descanso & A & $18.6-12.1$ & 14.5 & 71.4 & 146.6 & 32.3 & 11.9 & -31.0 & 11.6 & -2.7 & 9.8 & Rousse et al. [2005] \\
\hline 5 & Huaccochullo & A & $26.5-12.1$ & 16.0 & 70.5 & 166.4 & 25.8 & 6.5 & -11.3 & 6.4 & -11.4 & 5.6 & Rousse et al. [2005] \\
\hline 6 & Arica & FA & $\sim 19$ & 18.5 & 70 & 358.0 & -34.0 & 8.0 & 1.3 & 7.9 & -3.7 & 6.4 & Roperch et al. [1999] \\
\hline \multicolumn{14}{|c|}{ Southern Limb } \\
\hline 7 & Inchasi & $\mathrm{EC}$ & $4-3$ & 19.7 & 65.3 & 356.3 & -31.1 & 5.6 & -1.1 & 5.6 & -9.2 & 4.8 & MacFadden et al. [1993] \\
\hline 8 & Los Frailes & $\mathrm{EC}$ & $13-2$ & 19.5 & 66.3 & 006.7 & -43.3 & 6.9 & 9.9 & 7.7 & 2.8 & 5.7 & this study \\
\hline 9 & $\begin{array}{c}\text { Quebrada } \\
\text { Honda }\end{array}$ & $\mathrm{EC}$ & $13-12$ & 22.0 & 65.5 & 018.0 & -41.0 & 4.0 & 21.0 & 4.8 & -2.4 & 3.6 & MacFadden et al. [1990] \\
\hline 10 & Quehua & A & $13-7$ & 20.0 & 67.0 & 015.0 & -38.0 & 9.0 & 18.0 & 9.4 & -2.6 & 7.4 & MacFadden et al. [1995] \\
\hline 11 & Cerdas & A & $17-15$ & 20.8 & 66.7 & 010.0 & -39.0 & 7.0 & 13.0 & 7.5 & -2.7 & 5.8 & MacFadden et al. [1995] \\
\hline 12 & $\begin{array}{l}\text { Altiplano } \\
\text { volcanics }\end{array}$ & A & $14-7$ & 20.0 & 68.0 & 009.5 & -47.2 & 11.6 & 12.5 & 13.9 & 6.7 & 9.4 & $\operatorname{Lamb}[2001 \mathrm{a}]$ \\
\hline 13 & El Loa & FA & 11.3 & 22.3 & 68.6 & 001.0 & -46.0 & 7.0 & 4.3 & 8.3 & 3.0 & 5.6 & Somoza et al. [1999] \\
\hline 14 & Rinconada & $\mathrm{P}$ & 13 & 22.4 & 66.2 & 004.8 & -43.3 & 8.6 & 7.8 & 9.7 & -0.5 & 7.1 & after Prezzi and Alonso [2002] \\
\hline 15 & $\begin{array}{l}\text { Lomo Blanca } \\
\text { mine }\end{array}$ & $\mathrm{P}$ & 7 & 23.1 & 66.4 & 001.3 & -41.6 & 12.7 & 4.3 & 13.9 & -3.1 & 10.3 & after Prezzi and Alonso [2002] \\
\hline 16 & Morro Blanco & $\mathrm{P}$ & 10 & 23.0 & 66.5 & 356.9 & -41.1 & 2.9 & -0.3 & 3.8 & -3.5 & 2.8 & after Prezzi and Alonso [2002] \\
\hline 17 & Tiomayo & $\mathrm{P}$ & 13.5 & 22.5 & 66.5 & 001.9 & -35.8 & 6.3 & 4.9 & 6.6 & -8.1 & 5.3 & after Prezzi and Alonso [2002] \\
\hline 18 & Lipiyoc & $\mathrm{P}$ & 9 & 22.5 & 67.0 & 001.0 & -46.0 & 7.0 & 4.0 & 8.3 & 11.1 & 5.8 & Somoza et al. [1999] \\
\hline 19 & Monteagudo & SA & $15-25$ & 20.5 & 64.0 & 005.0 & -32.0 & 7.0 & 8.0 & 6.9 & -9.5 & 5.8 & $\operatorname{Lamb}[2001 \mathrm{a}]$ \\
\hline 20 & Bermejo & SA & $15-25$ & 22.4 & 64.5 & 035.0 & -44.0 & 19.0 & 38.0 & 21.6 & 0.1 & 15.3 & Lamb [2001a] \\
\hline
\end{tabular}

${ }^{\mathrm{a}}$ See Figure 1

${ }^{\mathrm{b}}$ A, Altiplano; P, Argentine Puna; EC, Eastern Cordillera; SA, sub-Andes.

${ }^{\mathrm{c}}$ Locality mean primary magnetization: $\mathrm{D}$, declination; I, inclination; $\alpha_{95}, 95 \%$ uncertainty limits.

${ }^{\mathrm{d}}$ Rotation $(\mathrm{R})$ and flattening $(\mathrm{F})$ with $95 \%$ uncertainty limits $(\Delta \mathrm{R}$ and $\Delta \mathrm{F})$ anomalies with respect to 10 Ma Stable South America reference pole $[$ Besse and Courtillot, 2002].

of predominantly anticlockwise rotations on the northern limb of the orocline (in Peru and northern Bolivia), and predominantly clockwise rotations on the southern limb (in northern Argentina, Chile and southern Bolivia). Rotations are generally less than $30^{\circ}$, but locally are up to $70^{\circ}$, with the largest rotations observed in Mesozoic to Eocene rocks, and significantly less in Neogene units. In addition, there are marked variations in the amount of rotation of Mesozoic to Paleogene units outcropping within a few tens of kilometers of each other.

[5] This pattern of tectonic rotations has been explained by two end-member models: (1) oroclinal bending, where rotations reflect bending of the entire mountain chain [Heki et al., 1985; Kono et al., 1985; Isacks, 1988; Lamb et al., 1997; Roperch et al., 1999, 2000; Lamb, 2001a, 2001b; Richards et al., 2004]; and (2) rotation of small (kilometer to tens of kilometer scale) local fault-bounded blocks, where rotations are the result of distributed dextral (south of the bend) or sinistral (north of the bend) shear, related to accommodation of the relative plate convergence [Hartley et al., 1988; Scanlan and Turner, 1992; Somoza, 1994; Butler et al., 1995; Lamb, 2000, 2001b]. There is no general consensus about the amount of oroclinal bending, or when it occurred. For example, Prezzi and Alonso [2002] proposed a maximum of $5^{\circ}$ of oroclinal bending, whereas of Lamb [2001a], Rousse et al. [2002], Gilder et al. [2003], and Richards et al. [2004] consider regional bending up to $30^{\circ}$ accommodated by along strike gradients in shortening.
Lamb [2001a] suggested oroclinal bending initiated in the Eocene, coinciding with the onset of intense behind arc shortening in the Bolivian Andes, whereas Gilder et al. [2003] consider bending to be younger than latest Oligocene. In addition, oroclinal bending cannot explain rotations greater than $\sim 30^{\circ}$ on either limb. Geodetic data, together with the pattern of Quaternary deformation, suggest that bending is active today [Lamb, 2000].

\subsection{Aims of This Study}

[6] In this study, we focus on a series of mid Miocene and younger volcanic complexes (Los Frailes, Morococala and Eucalyptus volcanics), which outcrop on the western margin of the Eastern Cordillera and eastern margin of the Altiplano, between $\sim 17^{\circ}$ and $20^{\circ} \mathrm{S}$ and on both limbs of the Bolivian orocline (Figures 1-3). A paleomagnetic study of these complexes has the potential to place important constraints on the history of Late Cenozoic rotational deformation over a large area in the hinge region of the Bolivian orocline. Furthermore, a pilot study [Lamb, 2001a] of four sites from the Morococala and Los Frailes complexes showed that they yielded well-defined stable magnetizations which could be interpreted as primary.

\section{Geological Setting of Paleomagnetic Localities}

\subsection{Los Frailes Volcanics}

[7] The Los Frailes volcanic complex lies on the southern limb of the Bolivian orocline, where the underlying struc- 

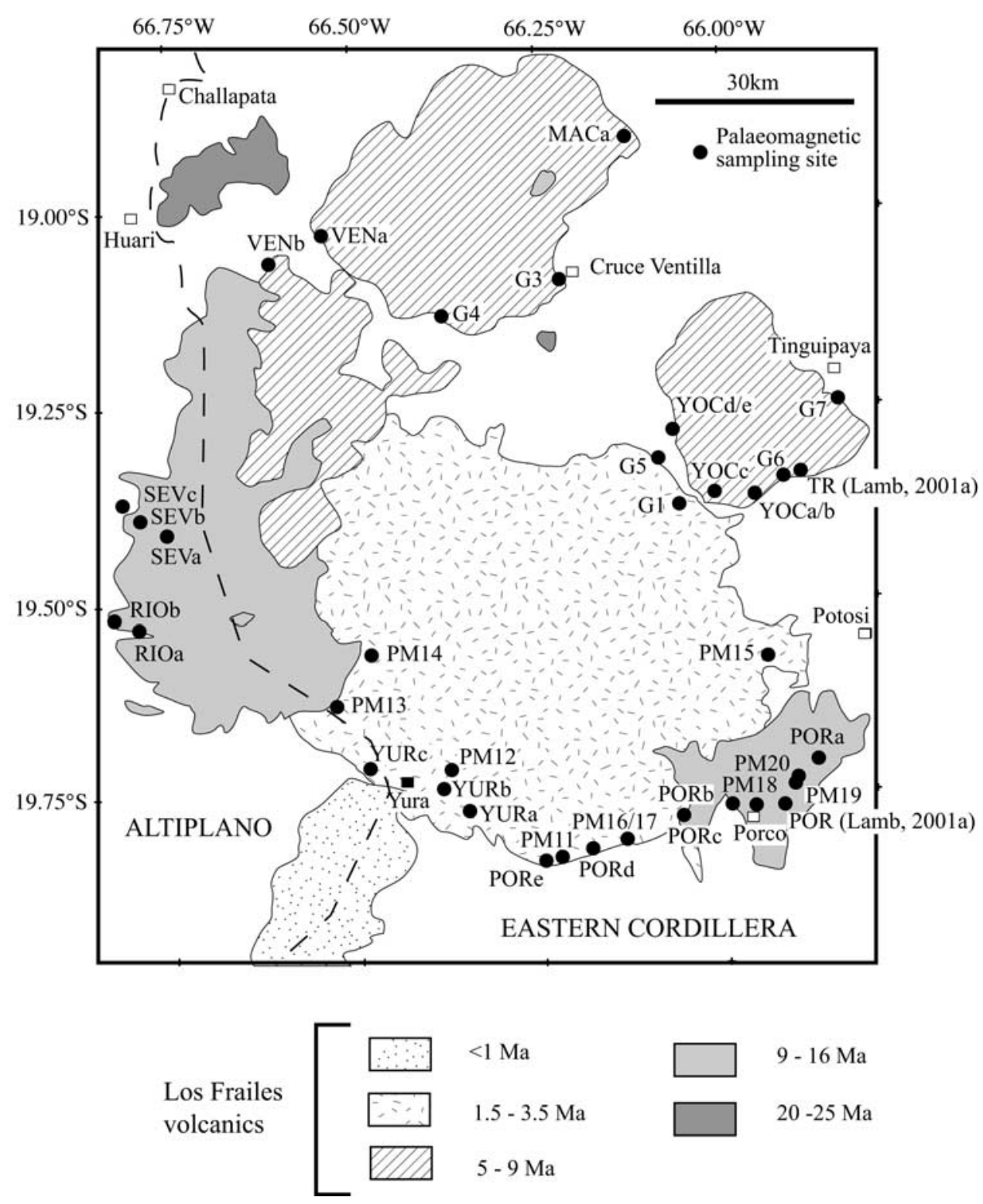

Figure 2. Los Frailes volcanic complex and the locations of paleomagnetic sites (see box in Figure 1 for location). The mapping of the volcanics is based on the interpretation of Schneider [1985] but adapted in the light of new geochronological data (Tables 2 and 3) [Barke, 2004] and the interpretation of Landsat 7 satellite imagery. Within each age grouping of volcanics, there are numerous flows. Paleomagnetic sampling was designed to sample as many discrete flows as possible. Also shown are the two paleomagnetic sites reported by Lamb [2001a].

tural trend is north to NNW. It straddles the boundary between the Eastern Cordillera and Altiplano, at an average elevation of $4000 \mathrm{~m}$, but with individual peaks rising over $5000 \mathrm{~m}$ (Figures 1 and 2). The complex is a composite field of caldera-type volcanism and extensive sheet ignimbrites, covering an area of $\sim 7500 \mathrm{~km}^{2}$, which have erupted mainly between $\sim 13$ and $\sim 2$ Ma (see ages in Tables 2 and 3), but has an older history of early Miocene mineralized stocks and domes [Grant et al., 1979; Schneider, 1985]. The flows show only moderate to weak compaction, suggesting rapid cooling after emplacement at moderate temperatures. They mantle a mid to late Miocene subhorizontal surface cut into folded Ordovician, Devonian, and Cretaceous sandstones, siltstones, and shales [Gubbels et al., 1993; Kennan et al., 1995, 1997; Barke, 2004]. Individual ignimbrite sheets can be several hundred meters thick and the units are neither faulted or folded [Schneider, 1985; Kennan et al., 1995; Lamb et al., 1997; Kennan et al., 1997; Barke, 2004]. The volcanism may have been a consequence of crustal melting during thermal reequilibration following early to middle Miocene crustal thickening in the Eastern Cordillera [Lamb et al., 1997], and/or the thermal effect of the addition of mafic melts into the crust [Hoke et al., 1994; Lamb et al., 1997; Lamb and Hoke, 1997; Myers et al., 1998].

[8] The detailed morphology of individual ignimbrite flows shows that they have not undergone significant tilting 

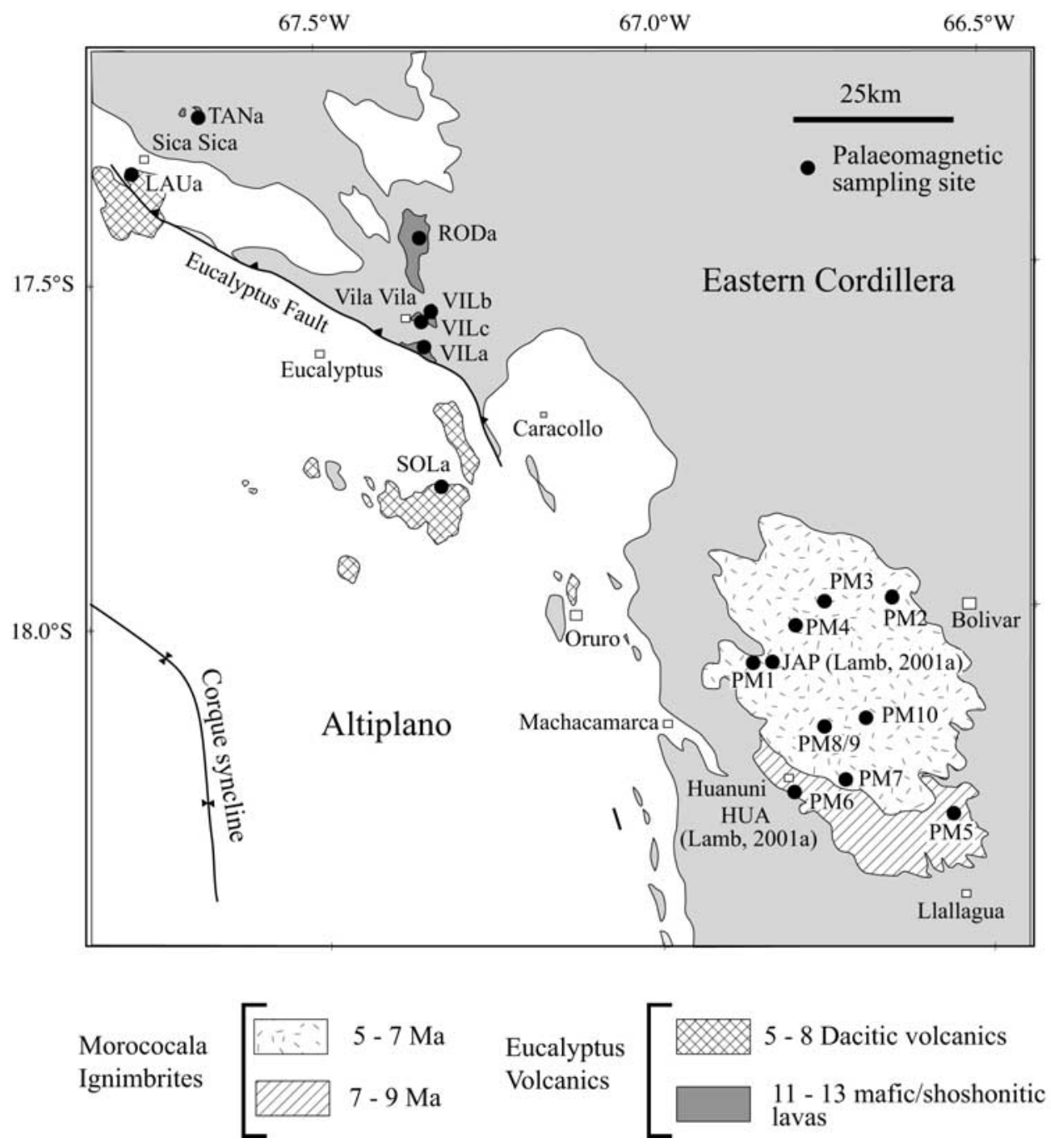

Figure 3. Morococala volcanic complex and the Eucalyptus Fault Zone and associated volcanics, showing the locations of paleomagnetic sampling sites (see Figure 1 for location). Age groupings of volcanics are based on published geochronological studies (see Table 4). Also shown are the two sampling sites reported by Lamb [2001a].

or faulting since they were emplaced, and surface topographic gradients $\left(<1^{\circ}\right)$ reflect the depositional tilt of the volcanic units [Barke, 2004].

\subsection{Morococala Volcanics}

[9] The Morococala volcanic complex has strikingly similar features to those of the Los Frailes. It lies on the northern limb of the Bolivian orocline, close to the hinge, and the underlying structural trend is NNW to NW (Figure 3).

[10] There was an initial phase of magmatism in the early Miocene (25-20 Ma), resulting in the intrusion of quartzlatite porphrytic bodies into intensely deformed Paleozoic indurated sands, silts and shales [Grant et al., 1979]. These are overlain by an extensive succession of 9-5 Ma rhyolitic ignimbrites (see ages in Table 4) that cover an area of approximately $1800 \mathrm{~km}^{2}$ at elevations between 4000 and $5000 \mathrm{~m}$. There is a prominent central volcano that may have been the source for the ignimbrites. On the eastern margin of the complex, the flows unconformably overlie the $\sim 19 \mathrm{Ma}$
Mondragon red bed sequence [Kennan et al., 1995]. As with the Los Frailes Formation, the well-preserved volcanic morphology of the flows clearly shows that they have not undergone significant internal folding or faulting since they were emplaced [Barke, 2004].

\subsection{Eucalyptus Volcanics}

[11] The Eucalyptus volcanic complex lies west of the Morococala volcanics, again on the northern limb of the Bolivian orocline and on the eastern margin of the Altiplano, and it outcrops as a chain of low hills rising above the general elevation of $4000 \mathrm{~m}$ (Figure 3). It occurs in the vicinity of a major NE to north trending fault (referred to as the Eucalyptus fault zone), between the towns of Sica Sica and Oruro, which juxtaposes Paleozoic sequences on the hanging wall with Cenozoic red beds in the footwall.

[12] In the early Miocene, between $\sim 25$ and $\sim 13 \mathrm{Ma}$, the Eucalyptus fault zone was active, accommodating convergence between the Eastern Cordillera and the Altiplano by thrusting with a component of sinistral strike-slip motion 
Table 2. Summary of New Ar-Ar Data for Biotite From Los Frailes Rhyolitic Ignimbrites ${ }^{\mathrm{a}}$

\begin{tabular}{|c|c|c|c|c|c|c|c|c|c|}
\hline$\underline{\text { Sample }}$ & $\begin{array}{c}\text { Grain Size }^{\mathrm{b}} \\
\mu \mathrm{m}\end{array}$ & $\begin{array}{c}\text { Weight, }^{\mathrm{b}} \\
\mathrm{mg}\end{array}$ & $\begin{array}{c}\mathrm{K},{ }^{\mathrm{c}} \\
\% \\
\end{array}$ & $\begin{array}{c}{ }^{40} \mathrm{Ar}^{*},{ }^{\mathrm{d}} \\
\mathrm{cm}^{3} \mathrm{~g}^{-1} \times 10^{-7}\end{array}$ & $\begin{array}{c}\text { A. } \mathrm{Ar}^{\mathrm{d}}{ }^{\mathrm{d}} \\
\%\end{array}$ & $\begin{array}{c}\text { Plateau Age, } \\
\text { Ma }\end{array}$ & $\begin{array}{c}\text { Isochron Age, } \\
\mathrm{Ma}\end{array}$ & MSWD $^{\mathrm{e}}$ & $\begin{array}{l}{ }^{40} \mathrm{Ar} /{ }^{36} \mathrm{Ar} \\
\text { Trapped } \mathrm{Ar}\end{array}$ \\
\hline G1 & $420-840$ & 19.1 & 7.22 & 26.20 & 93.3 & $2.24 \pm 0.09$ & $2.60 \pm 0.95$ & 0.3 & $296 \pm 4.5$ \\
\hline $\mathrm{G} 4^{\mathrm{f}}$ & $>840$ & 19.0 & 4.09 & 8.84 & 48.7 & $4.81 \pm 0.18$ & $4.90 \pm 0.55$ & 2.0 & $313 \pm 21$ \\
\hline MACa & $420-840$ & 15.1 & 5.11 & 22.46 & 56.9 & $9.23 \pm 0.17$ & $9.24 \pm 0.38$ & 0.2 & $296 \pm 6.0$ \\
\hline $\mathrm{SEVb}^{\mathrm{f}}$ & $250-420$ & 21.6 & 6.11 & 44.81 & 28.7 & $9.45 \pm 0.12$ & NSC & - & - \\
\hline YURb & $420-840$ & 17.6 & 6.61 & 5.11 & 58.6 & $1.86 \pm 0.09$ & $1.28 \pm 0.24$ & 0.3 & $306 \pm 11$ \\
\hline
\end{tabular}

${ }^{\mathrm{a}}$ From Barke [2004]. All measurements were carried out at the Department of Earth Sciences, University of Manchester, in the laboratory of R. Burgess. Samples were irradiated in position B2W of the SAFARI-1 reactor in the South African Nuclear Energy Corporation's Pelindaba site, Johannesburg, South Africa; full details of analytical procedures are given by Barke [2004]

${ }^{\mathrm{b}}$ Grain size and weight of sample fraction analyzed.

${ }^{\mathrm{c}} \mathrm{K}$, weight percent of potassium.

${ }^{\mathrm{d}}$ The amount of radiogenic argon present $\left({ }^{40} \mathrm{Ar} *\right)$ and the percent of atmospheric argon (A. Ar) are based on assumption that all trapped argon is of atmospheric composition.

${ }^{\mathrm{e}} \mathrm{MSWD}$, mean square of weighted deviates.

findicates that one temperature step was not analyzed owing to procedural errors; NSC, no statistically significant correlation on the isochron. All errors are quota at the one sigma level and include the error in the $\mathrm{J}$ value.

[Herail et al., 1993; Lamb and Hoke, 1997]. However, by $13 \mathrm{Ma}$, thrusting had ceased and the fault is sealed by a set of shoshonitic centers that erupted between 13 and $11 \mathrm{Ma}$ (see ages in Table 4). Subsequently, between 8 and $5 \mathrm{Ma}$, intermediate to acidic lavas and dike-like bodies (Soledad and Cerro Laurani [Redwood and MacIntyre, 1989; Herail et al., 1993]) were intruded into, and extruded onto, the Paleozoic basement and Cenozoic red beds of the Altiplano. Both the shoshonitic and younger acidic units have not been deformed by either faulting or folding, indicating that the focus of deformation had moved farther to the west since $\sim 11 \mathrm{Ma}$, concomitant with the growth of the Corque syncline in the central Altiplano [Lamb and Hoke, 1997; Roperch et al., 1999].

\section{Paleomagnetic Analysis}

\subsection{Paleomagnetic Site Selection and Sampling Procedure}

[13] Our aim was to obtain a wide geographical coverage from individual volcanic units throughout the volcanic complexes, as well as sample as many different flow units as possible so as to cover the whole period of volcanic activity. In this study, a paleomagnetic site refers to where a single instantaneous volcanic event or magnetic epoch has been sampled, whereas a locality refers to a suite of sites, sufficient to remove any bias due to paleosecular variation.

[14] The four sites reported by Lamb [2001a] were in the Los Frailes and Morococala volcanics, and samples were taken by drilling numerous cores. As it is clear that each site only represents a single paleomagnetic epoch (volcanic event), it was felt in this study that a simpler and faster protocol could be adopted: One to three orientated blocks, measuring roughly $10 \mathrm{~cm} \times 10 \mathrm{~cm} \times 15 \mathrm{~cm}$, were extracted from widely spaced positions at each site. This way, Lamb's pilot study could be substantially expanded in two field campaigns (2001 and 2002), with a total of 101 orientated blocks collected from 52 new sites. Road cuttings often provided the best sampling locations.

[15] Although there is no published detailed geological map of either the Los Frailes, Morococala or Eucalyptus volcanics, volcanic centers or flow units can be readily recognized and traced using Landsat 7 imagery combined with detailed digital (SRTM) topographic data and field observations [Barke, 2004]. For example, individual flows often have distinct spectral characteristics which can be enhanced in the satellite imagery, or they weather or erode in a way to give rise to particular surface morphologies. Consequently, there is very little ambiguity in the identification of flow units, but wherever any exist, a conservative approach has been taken by grouping potentially similar flows.

\subsection{Analytical Methods}

[16] In the laboratory, each orientated block was leveled and set in plaster. Orientated cores were then drilled out using a brass, diamond-tipped core barrel with an internal diameter of $25 \mathrm{~mm}$, and these were used for all further analysis.

[17] Measurements of the natural remanent magnetization (NRM) were made with a $2 \mathrm{G}$ Enterprises cryogenic magnetometer for specimens with a NRM intensity less than $5000 \mathrm{~mA} \mathrm{~m}^{-1}$, and with an AGICO JR5a spinner magnetometer for NRM intensities greater than $5000 \mathrm{~mA} \mathrm{~m}{ }^{-1}$. The $2 \mathrm{G}$ magnetometer is housed within a magnetically shielded room, with a residual field of 200-300 nT, in the Oxford Paleomagnetic laboratory.

[18] Progressive thermal demagnetization was performed using a MMTD60 furnace, with an internal residual field of less than 5 nT. For all thermal demagnetization, 17 heating steps were used up to a maximum temperature of $600^{\circ} \mathrm{C}$. The bulk magnetic susceptibility was measured after each heating step in order to monitor possible magnetic mineral changes for the first "pilot" samples. At each step, the order was reversed with which samples were loaded into the furnace. This way, any spurious magnetizations, which the samples may have acquired during the heating process, could be detected. Alternating field demagnetization was carried out with a 2G Model 600 alternating field (AF) demagnetizer, using 16 steps up to a maximum field strength of $100 \mathrm{mT}$. Eight specimens were partially demagnetized using an AF tumbling demagnetizer.

[19] High-temperature susceptibility measurements were performed using a Kappabridge KLY 2 instrument and CS-2 control unit, and isothermal remanent magnetization (IRM) experiments were carried out with a pulse electromagnet. 
Table 3. Paleomagnetic Data for the Los Frailes Rhyolitic Ignimbrites ${ }^{\mathrm{a}}$

\begin{tabular}{|c|c|c|c|c|c|c|c|c|c|c|c|c|}
\hline Sites $^{\mathrm{b}}$ & $\begin{array}{c}\text { Latitude, } \\
{ }^{\circ} \mathrm{S}\end{array}$ & $\begin{array}{c}\text { Longitude, } \\
{ }^{\circ} \mathrm{W}\end{array}$ & $\begin{array}{c}\text { Age } \\
(\text { Ref }),{ }^{\mathrm{c}} \mathrm{Ma}\end{array}$ & $\begin{array}{l}\mathrm{NRM}^{\mathrm{d}}{ }^{-1} \\
\mathrm{~mA} \mathrm{~m}^{-1}\end{array}$ & $\mathrm{n}^{\mathrm{e}}$ & $\mathrm{n}_{\mathrm{o}}{ }^{\mathrm{e}}$ & $\mathrm{D},{ }^{\mathrm{f}} \mathrm{deg}$ & $\mathrm{I},{ }^{\mathrm{f}} \operatorname{deg}$ & $\mathrm{k}^{\mathrm{g}}$ & $\mathrm{a}_{95}{ }^{\mathrm{g}}$ & Site Class ${ }^{\mathrm{h}}$ & Comments $^{\mathrm{i}}$ \\
\hline POR & -19.71 & -65.87 & $10-13$ & - & $9 / 5$ & - & 184.0 & 21.0 & 986.0 & 2.0 & A & after $\operatorname{Lamb}$ [2001a] \\
\hline PM18 & -19.770 & -65.957 & $10-13$ & 660 & $6 / 1$ & $6 / 1$ & 179.7 & 29.1 & 757.8 & 2.4 & A & \\
\hline PM19 & -19.741 & -65.906 & $10-13$ & 210 & $6 / 1$ & $6 / 1$ & 165.2 & 42.2 & 1083.3 & 2.0 & A & \\
\hline PM20 & -19.735 & -65.904 & $10-13$ & 930 & $6 / 1$ & $7 / 1$ & 172.2 & 34.3 & 457.0 & 3.1 & A & \\
\hline PORa & -19.710 & -65.871 & $10-13$ & $10-50$ & $6 / 3$ & $6 / 3$ & 173.0 & 26.9 & 335.0 & 3.0 & A & \\
\hline PORb & -19.767 & -65.991 & $10-13$ & $610-690$ & $5 / 2$ & $7 / 3$ & 170.9 & 36.2 & 91.5 & 9.7 & A & \\
\hline Mean & & & $10-13(3,4)$ & & & 6 sites & 174.6 & 31.8 & 74.4 & 7.8 & & \\
\hline PORc & -19.786 & -66.040 & $1.9-2.2$ & $150-330$ & $7 / 3$ & $7 / 3$ & 170.6 & 45.9 & 106.2 & 5.9 & A & \\
\hline PORd & -19.831 & -66.183 & $1.9-2.2$ & 290,22710 & $4 / 1$ & $6 / 2$ & 178.0 & 48.6 & 336.7 & 5.0 & A & block $2=1 \mathrm{~s}$ \\
\hline PORe & -19.848 & -66.242 & $1.9-2.2$ & $90-180$ & $7 / 3$ & $7 / 3$ & 175.1 & 54.9 & 215.9 & 4.1 & A & \\
\hline PM16/17 & -19.820 & -66.134 & $1.9-2.2$ & 10500,4490 & - & $12 / 2$ & - & - & - & - & B & ncc, $\mathrm{PM} 16=1 \mathrm{~s}$ \\
\hline Mean & & & $1.9-2.2(5)$ & & & 3 sites & 174.5 & 49.8 & 239.5 & 8.0 & & \\
\hline PM11 & -19.843 & -66.226 & & 2070 & - & $7 / 1$ & - & - & - & - & B & nec within block \\
\hline YURa & -19.772 & -66.347 & & $140-670$ & - & $6 / 3$ & - & - & - & - & B & ncc between blocks \\
\hline YURb & -19.741 & -66.381 & $1.9 \pm 0.1(5)$ & $170-260$ & $6 / 3$ & $6 / 3$ & 28.0 & -52.5 & 64.5 & 8.4 & A & \\
\hline PM12 & -19.720 & -66.374 & $<1.9(5)$ & 510 & $6 / 1$ & $6 / 1$ & 201.9 & 33.2 & 728.0 & 2.5 & A & \\
\hline YURc & -19.719 & -66.483 & $<1.9$ (5) & $370-2120$ & $6 / 3$ & $6 / 3$ & 181.7 & 64.9 & 78.2 & 7.6 & A & \\
\hline PM13 & -19.634 & -66.527 & & 1140 & - & $5 / 1$ & - & - & - & - & B & nce within block \\
\hline PM14 & -19.571 & -66.476 & & 2320 & - & $7 / 1$ & - & - & - & - & B & nec within block \\
\hline RIOa & -19.529 & -66.792 & & $100-1340$ & - & $8 / 3$ & - & - & - & - & B & ncc between blocks \\
\hline RIOb & -19.527 & -66.830 & $9-10(3)$ & $360-450$ & $8 / 3$ & $8 / 3$ & 17.3 & -51.3 & 89.0 & 5.9 & A & \\
\hline SEVa & -19.412 & -66.752 & $9-10(3)$ & 40 & $3 / 1$ & $3 / 1$ & 355.6 & -48.1 & 729.3 & 4.6 & A & \\
\hline $\mathrm{SEVb}$ & -19.393 & -66.793 & $9.5 \pm 0.1$ & $390-2040$ & $7 / 3$ & $7 / 3$ & 355.9 & -44.6 & 35.2 & 10.3 & A & \\
\hline SEVc & -19.374 & -66.825 & $9-10(3)$ & $390-460$ & $7 / 3$ & $7 / 3$ & 360.0 & -54.8 & 27.2 & 11.8 & A & \\
\hline PM15 & -19.578 & -65.942 & $2.2 \pm 0.1$ & 920 & $6 / 1$ & $6 / 1$ & 177.7 & 51.7 & 220.4 & 4.5 & A & \\
\hline G1 & -19.377 & -66.056 & $2.2 \pm 0.1$ & 870 & $6 / 1$ & $6 / 1$ & 210.4 & 23.0 & 255.3 & 4.2 & A & \\
\hline G5 & -19.323 & -66.085 & $2.2 \pm 0.1(5)$ & 700 & $4 / 1$ & $4 / 1$ & 172.4 & 35.7 & 636.4 & 3.6 & A & \\
\hline G6 & -19.350 & -65.913 & $6.5-7.5$ & 30 & $6 / 1$ & $6 / 1$ & 19.8 & -43.6 & 782.4 & 2.4 & A & \\
\hline TR & -19.30 & -66.00 & $6.5-7.5$ & - & $10 / 6$ & - & 15.0 & -46.0 & 419.0 & 2.0 & A & after $\operatorname{Lamb}$ [2001a] \\
\hline Mean & & & $6.5-7.5(4)$ & & & & 17.4 & -44.8 & 756.9 & 9.1 & & \\
\hline YOCa & -19.369 & -65.955 & $6.5-7.5(1,4)$ & 10,20 & $6 / 2$ & $6 / 2$ & 181.7 & 34.8 & 194.0 & 4.8 & A & \\
\hline $\mathrm{YOCb}$ & -19.369 & -65.955 & $6.5-7.5(1,4)$ & 30,50 & $3 / 1$ & $6 / 2$ & 13.4 & -31.1 & 834.4 & 4.3 & A & \\
\hline YOCc & -19.367 & -66.011 & $6.5-7.5(1,4)$ & $500-890$ & $6 / 2$ & $6 / 2$ & 357.9 & -15.9 & 57.9 & 8.9 & A & \\
\hline YOCd & -19.284 & -66.063 & $6.5-7.5(1,4)$ & $440-780$ & $6 / 2$ & $6 / 2$ & 125.6 & -13.7 & 102.5 & 6.6 & A & \\
\hline YOCe & -19.284 & -66.062 & $6.5-7.5(1,4)$ & 600,1390 & $6 / 2$ & $6 / 2$ & 126.8 & -7.2 & 19.9 & 15.4 & A & \\
\hline G7 & -19.249 & -65.840 & $6.5-7.5(1,4)$ & 110 & $6 / 1$ & $6 / 1$ & 2.4 & -33.4 & 529.7 & 2.9 & A & \\
\hline G3 & -19.091 & -66.218 & $5-8(1)$ & 1640 & $6 / 1$ & $6 / 1$ & 3.0 & -36.0 & 1648.0 & 1.7 & A & \\
\hline G4 & -19.134 & -66.378 & $4.8 \pm 0.2(5)$ & 110 & $6 / 1$ & $6 / 1$ & 16.8 & -70.2 & 591.9 & 2.8 & A & \\
\hline MACa & -18.907 & -66.124 & $9.2 \pm 0.2(5)$ & $330-960$ & $6 / 3$ & $6 / 3$ & 195.6 & 60.6 & 79.7 & 7.6 & A & \\
\hline VENa & -18.221 & -66.554 & $5-6(3)$ & $250-79640$ & - & $8 / 3$ & - & - & - & - & B & ncc, block $3=1 \mathrm{~s}$ \\
\hline VENb & -19.066 & -66.611 & $5-6(3)$ & $10-1310$ & $5 / 3$ & $7 / 3$ & 191.0 & 18.5 & 63.1 & 9.7 & A & block $2=$ ncc \\
\hline
\end{tabular}

${ }^{\mathrm{a}}$ See Figure 2.

${ }^{\mathrm{b}} \mathrm{A}$ mean magnetization is determined for flows sampled at more than one site.

'Numbers in parentheses refer to source of age determination: (1) K-Ar biotite ages from Evernden et al. [1977]; (2) K-Ar biotite ages from Baker and Francis [1978]; K-Ar biotite ages from Schneider [1985]; (4) K-Ar biotite ages from Kennan et al. [1995]; Ar-Ar biotite ages in this study (see Table 2).

${ }^{\mathrm{d} N R M}$, means for each block at each site.

'The variable $\mathrm{n}$, number of specimens/number of blocks used in the statistics; $\mathrm{n}_{\mathrm{o}}$, total number of specimens/number of blocks analyzed.

${ }^{\mathrm{f}} \mathrm{D}$, declination; I, inclination of primary remnant magnetism.

${ }^{\mathrm{g}}$ The $\mathrm{k}$, Fisher precision parameter; $\alpha_{95}$, radius of $95 \%$ confidence cone.

${ }^{\mathrm{h}}$ Site class refers to demagnetization behavior (class A have clear primary components, class B components are less certain).

${ }^{i}$ Abbreviations are 1s, lightning strike; ncc, no consistent components.

[20] An average of 6 (minimum 4, maximum 12) specimens were demagnetized from each paleomagnetic site. At least two specimens from each block were demagnetized for multiple block sites. Initially, one specimen from each site was thermally demagnetized and one demagnetized using AF treatment, and results of this determined which technique was most appropriate for further demagnetization.

[21] All demagnetization data were evaluated using principal component analysis [e.g., Kirschvink, 1980]. Sitemean directions were determined by applying Fisher's [1953] statistics, except for a few sites where the method of combining great circles and stable end-point directions [McFadden and McElhinny, 1988], and great circle analysis
[Hoffman and Day, 1978], were used, respectively. For flow units sampled at more than one site, the mean direction was calculated by averaging individual site-mean directions.

\section{Paleomagnetic Results}

\subsection{Demagnetization of Los Frailes Volcanics}

[22] The paleomagnetic results from the Los Frailes volcanics are listed in Table 3. Example demagnetization and rock magnetic behavior are shown in Figures 4 to 6 . The demagnetization behavior of the Los Frailes sites is broadly divided into two classes. Class A sites comprise 29 of the 36 total sites and show very simple demagnetization 
Table 4. Paleomagnetic Data for the Morococala and Eucalyptus Volcanics ${ }^{\mathrm{a}}$

\begin{tabular}{|c|c|c|c|c|c|c|c|c|c|c|c|c|}
\hline Sites $^{\mathrm{b}}$ & $\begin{array}{c}\text { Latitude, } \\
\text { deg }\end{array}$ & $\begin{array}{c}\text { Longitude, } \\
\text { deg }\end{array}$ & Lithology & $\begin{array}{c}\text { Age } \\
\left(\text { Ref) },{ }^{\mathrm{c}} \mathrm{Ma}\right.\end{array}$ & $\begin{array}{l}\mathrm{NRM}^{\mathrm{d}}{ }^{-1} \\
\mathrm{~mA} \mathrm{~m}^{-1}\end{array}$ & $\mathrm{n}^{\mathrm{e}}$ & $\mathrm{n}_{\mathrm{o}}{ }^{\mathrm{e}}$ & $\begin{array}{l}\mathrm{D},{ }^{\mathrm{f}} \\
\mathrm{deg}\end{array}$ & $\begin{array}{l}\mathrm{I},{ }^{\mathrm{f}} \\
\mathrm{deg}\end{array}$ & $\mathrm{k}^{\mathrm{g}}$ & $\alpha_{95}{ }^{\mathrm{g}}$ & Comments $^{\mathrm{h}}$ \\
\hline JAP & -18.0 & -66.8 & Rhyoltic ignimbrite & $6 \pm 1$ & - & $4 / 3$ & - & 175.0 & 11.0 & 125.0 & 8.0 & after Lamb [2001a] \\
\hline PM1 & -18.064 & & & $6 \pm$ & 2 & $6 / 1$ & $6 / 1$ & 183.1 & 4.1 & 79.7 & 8.6 & \\
\hline Mean & & & & $6 \pm 1(1-3)$ & & 2 sites & & 179.1 & 7.6 & 117.3 & 23.3 & \\
\hline PM2 & -18.017 & -66.785 & Rhyoltic ignimbrite & $6 \pm 1$ & 730 & $6 / 1$ & $6 / 1$ & 316.4 & -62.5 & 793.8 & 2.4 & \\
\hline PM3 & -17.978 & -66.642 & Rhyoltic ignimbrite & $6 \pm$ & 760 & $5 / 1$ & $6 / 1$ & 306.6 & -64.5 & 206.7 & 4.7 & \\
\hline PM4 & -17.982 & -66.7 & Rhyoltic ignimbrite & $6 \pm$ & 2110 & $6 / 1$ & $6 / 1$ & 305.0 & -65.7 & 112.5 & 6.3 & \\
\hline Mean & & & & $6 \pm 1(1-3)$ & & 3 sites & & 309.6 & -64.3 & 658.6 & 4.8 & \\
\hline PM8/9 & -18.163 & -66.748 & Rhyoltic ignimbrite & $6 \pm 1$ & $760-10410$ & $7 / 1$ & $13 / 2$ & 339.1 & -52.0 & 40.5 & 9.6 & PM9 $=1 \mathrm{~s}$ \\
\hline PM10 & -18.151 & -66.685 & Rhyoltic ignimbrite & $6 \pm 1$ & 760 & $6 / 1$ & $6 / 1$ & 303.0 & -64.5 & 984.0 & 2.1 & \\
\hline Mean & & & & $6 \pm 1(1-3)$ & & 2 sites & & 324.4 & -59.5 & 26.6 & 50.5 & \\
\hline UA & -18.200 & -66 . & $\mathrm{R}$ & $6 \pm 1$ & - & $11 / 10$ & - & 163.0 & 31.0 & 70.0 & 6.0 & after $\operatorname{Lamb}$ [2001a] \\
\hline PM6 & -18 & -66.796 & Rhyoltic ignimbrite & $6 \pm$ & 200 & $6 / 1$ & $6 / 1$ & 164.6 & 11.2 & 274.3 & 4.1 & \\
\hline Mean & & & & $6 \pm 1(1-3)$ & & 2 sites & & 163.9 & 21.1 & 33.4 & 44.7 & \\
\hline PM5 & -18.290 & -66.552 & $\mathrm{R}$ & $8 \pm 1(1-3)$ & 20 & $4 / 1$ & $4 / 1$ & 216.4 & 49.1 & 99.3 & 9.3 & \\
\hline & & -66 & Rhyoltic & $6 \pm 1$ & 28 & $6 / 1$ & $6 / 1$ & 350.6 & -44.9 & 34.8 & 11.5 & \\
\hline La & -17.805 & -67.317 & & $5-6$ & $0-8260$ & - & $5 / 3$ & - & - & - & - & ncc between blocks \\
\hline VILa & -17.604 & -67.339 & $\mathrm{~S}$ & $11 \pm 1$ & $1560-6$ & $9 / 3$ & $9 / 3$ & 359.3 & -24.2 & 72.9 & 6.7 & GC with fixed poin \\
\hline VILc & -17.565 & -67.341 & Shoshonitic lava & $11-12(4,5)$ & 38760,23560 & - & $5 / 2$ & - & - & - & - & \\
\hline VILb & -17.555 & -67.331 & Shoshonitic lava & $11-12(4,5)$ & $6330-35770$ & $6 / 2$ & $9 / 3$ & 189.6 & 14.4 & 682.5 & 3.3 & bloc \\
\hline & -17.443 & -67.344 & Shoshonitic lava & $12 \pm 1(4,5)$ & & - & $6(3)$ & - & - & - & - & ncc between blocks \\
\hline LAUa & -17.342 & -67.774 & & $8-9(4,5)$ & $9490-29850$ & - & $6(3)$ & - & - & - & - & ncc \\
\hline TANa & -17.264 & -67.671 & Shoshonitic lava & $12-13(4,5)$ & $2160-114090$ & $5 / 2$ & $10 / 3$ & 0.1 & -9.8 & 475.2 & 3.5 & ncc between blocks \\
\hline
\end{tabular}

${ }^{\mathrm{a}}$ See Figure 3 .

${ }^{\mathrm{b}} \mathrm{A}$ mean magnetization is determined for flows sampled at more than one site.

${ }^{\mathrm{c}}$ Numbers in parentheses refer to source of age determination: (1) K-Ar age for biotite from Grant et al. [1979]; (2) K-Ar ages for biotite from Servicio Geologico de Bolivia and SGAB International Suecia [1992]; (3) K-Ar ages for biotite from Servicio Geologico de Bolivia and SGAB International Suecia [1993]; (4) K-Ar age from Redwood and MacIntyre [1989]; (5) Ar-Ar age from Herail et al. [1993].

${ }^{\mathrm{d}} \mathrm{NRM}$, means for each block at each site.

'The variable $\mathrm{n}$, number of specimens/number of blocks used in the statistics; $\mathrm{n}_{\mathrm{o}}$, total number of specimens/number of blocks analyzed.

${ }^{\mathrm{f}} \mathrm{D}$, declination; I, inclination of primary remnant magnetism.

${ }^{\mathrm{g}}$ The variable $\mathrm{k}$, Fisher precision parameter; $\alpha_{95}$, radius of $95 \%$ confidence cone.

${ }^{\mathrm{h}}$ Abbreviations are ls, lightning strike; ncc, no consistent components.

behavior with a high consistency of component directions both within and between blocks. The 7 class B sites have either no component consistency within blocks, or no consistency between blocks.

\subsubsection{Class A Sites}

[23] The NRM intensity in class A samples varies from $10 \mathrm{~mA} \mathrm{~m}^{-1}$ (PORa) to $2000 \mathrm{~mA} \mathrm{~m}^{-1}$ (SEVb) with a modal value of $\sim 500 \mathrm{~mA} \mathrm{~m}^{-1}$. The variation in NRM intensity between specimens from the same block is low (typically within $10 \%$ of the mean NRM) and variation between blocks is often low (e.g., RIOb), but always within an order of magnitude (YURa). These variations in NRM most likely reflect variations in the magnetic mineral content of the samples. Thermal demagnetization unblocks $>95 \%$ of the $\mathrm{NRM}$ by $580^{\circ} \mathrm{C}$ (Figure 4, G3f2) suggesting that magnetite is the principal magnetic carrier. Alternating field demagnetization to $100 \mathrm{mT}$ typically removes between 50 and $80 \%$ of the initial intensity (Figure 4, G3a2), suggesting that a higher coercivity magnetic phase is present. IRM acquisition and high-temperature susceptibility experiments were performed on samples from 7 sites. For all samples, saturation magnetization was reached by $300 \mathrm{mT}$, and the bulk coercivity of remanence varied between 20 and $80 \mathrm{mT}$ (Figure 4, YOCc3). Clear breaks in susceptibility were observed between 500 and $600^{\circ} \mathrm{C}$. All these observations are consistent with magnetite being the principal remanence carrier.

[24] In all class A sites, there is one stable and consistent high-temperature/coercivity component (the principal component) of magnetization that comprises between 50 and $100 \%$ of the total NRM (Figures 4 and 5). Sometimes, there are occasional secondary low-unblocking temperature components, however, these are generally removed by $400^{\circ} \mathrm{C}$ (Figure 5, YURb3). The unblocking temperature spectra of the low-temperature component typically overlap that of the principal component and no consistent orientation of this secondary low-temperature overprint has been observed. The principal components between specimens group well and all sites yield mean $\alpha_{95}$ values less than $16^{\circ}$, with 24 less than $8^{\circ}$. Where flow units have been sampled by multiple sites, the principal components always have the same polarity, and block mean directions for flow units with multiple sites group well, with $\alpha_{95}$ values less than $10^{\circ}$. These first-order observations, combined with the demagnetization behavior, suggest that the Los Frailes ignimbrites were emplaced above the blocking temperatures of the magnetite grains, and cooled relatively quickly (i.e., they did not cool across geomagnetic reversals).

\subsubsection{Class B Sites}

[25] Samples from class B sites (Figure 6) have NRM intensities similar to those of class A. IRM and hightemperature susceptibility experiments again show that magnetic is the principal magnetic phase present. However, the thermal demagnetization behavior is significantly different to those of class $\mathrm{A}$, with intensity dropping off steadily between 0 and $600^{\circ} \mathrm{C}$, as opposed to steep drop offs at $500-550^{\circ} \mathrm{C}$ (Figure 6, YURa). Magnetization com- 

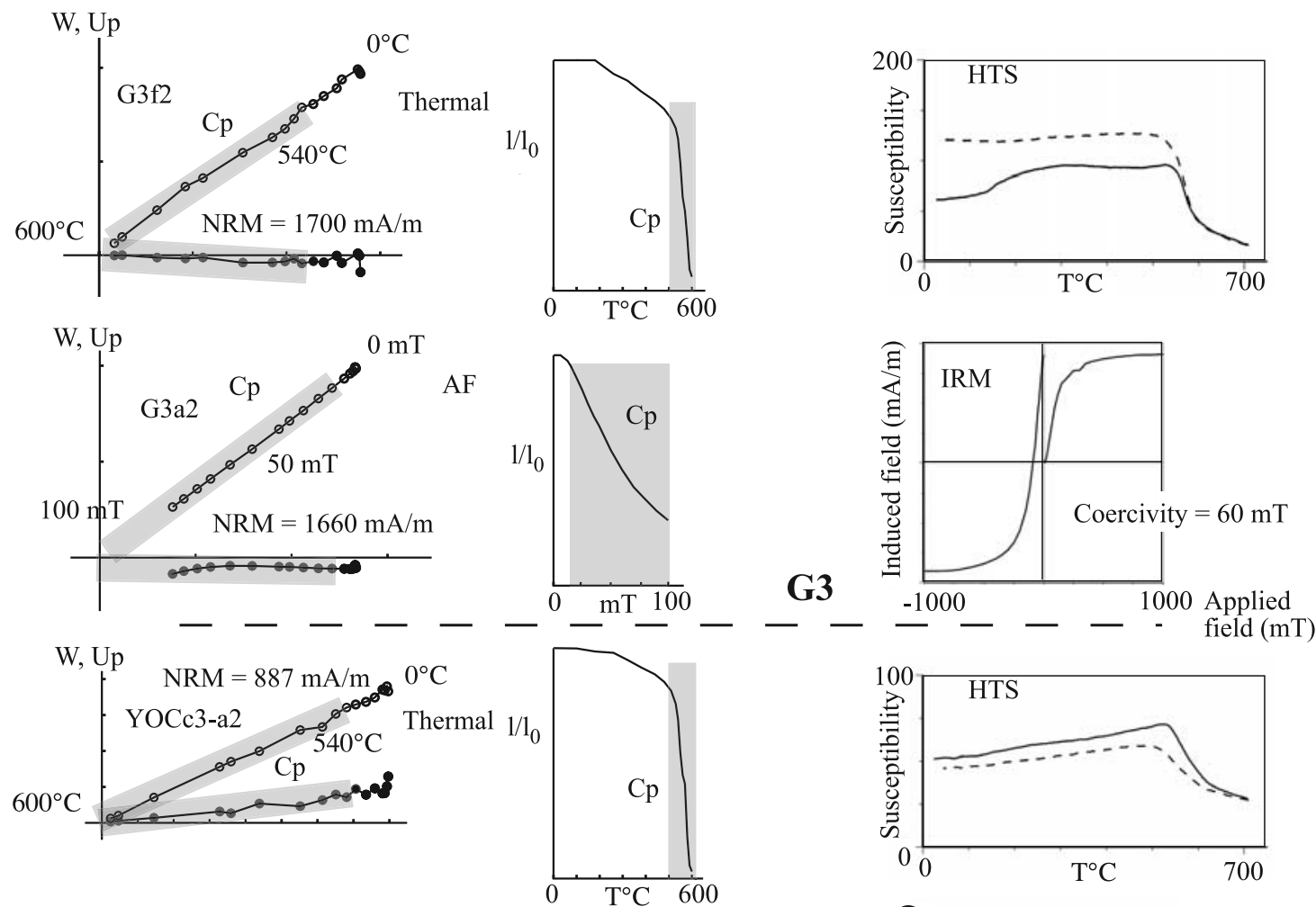

G3
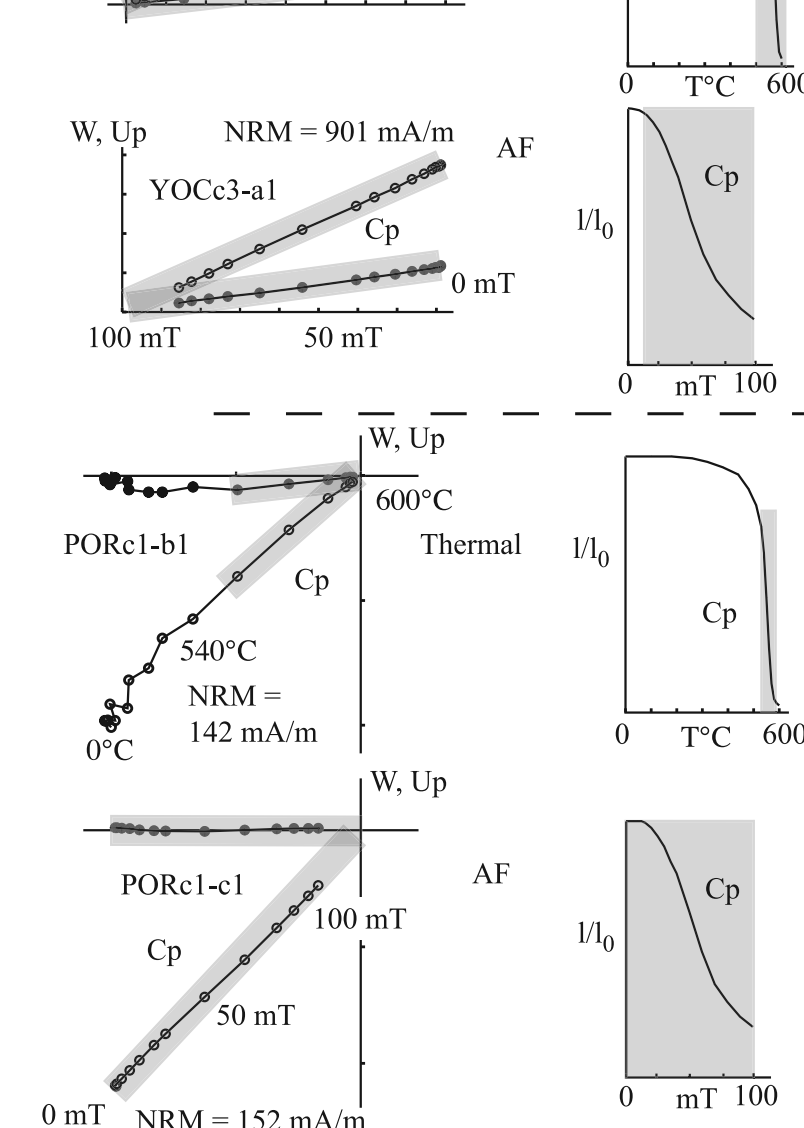

YOCc3
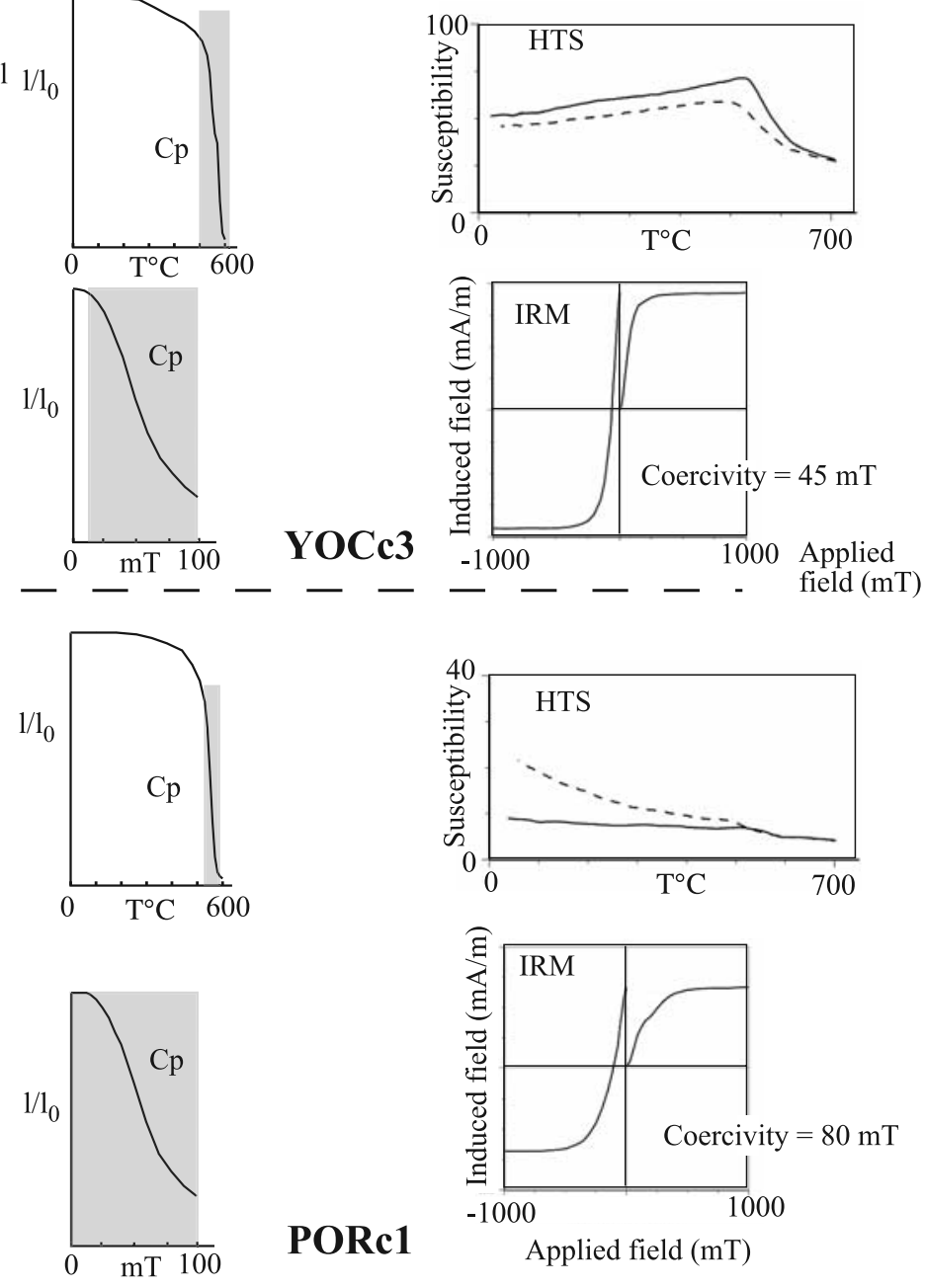

Figure 4. Demagnetization data for class A sites from the Los Frailes volcanics. For explanation, see caption to Figure 5.

ponent directions are either not consistent within blocks (Figure 6), or are consistent within blocks but are not consistent between blocks (e.g., YURa). A qualitative assessment of the freshness of the blocks, combined with the fact that significant thermal demagnetization occurred below $500^{\circ} \mathrm{C}$, suggests that it is likely that these sites have been significantly weathered and the primary magnetization lost. However, the possibility that these flows were erupted 

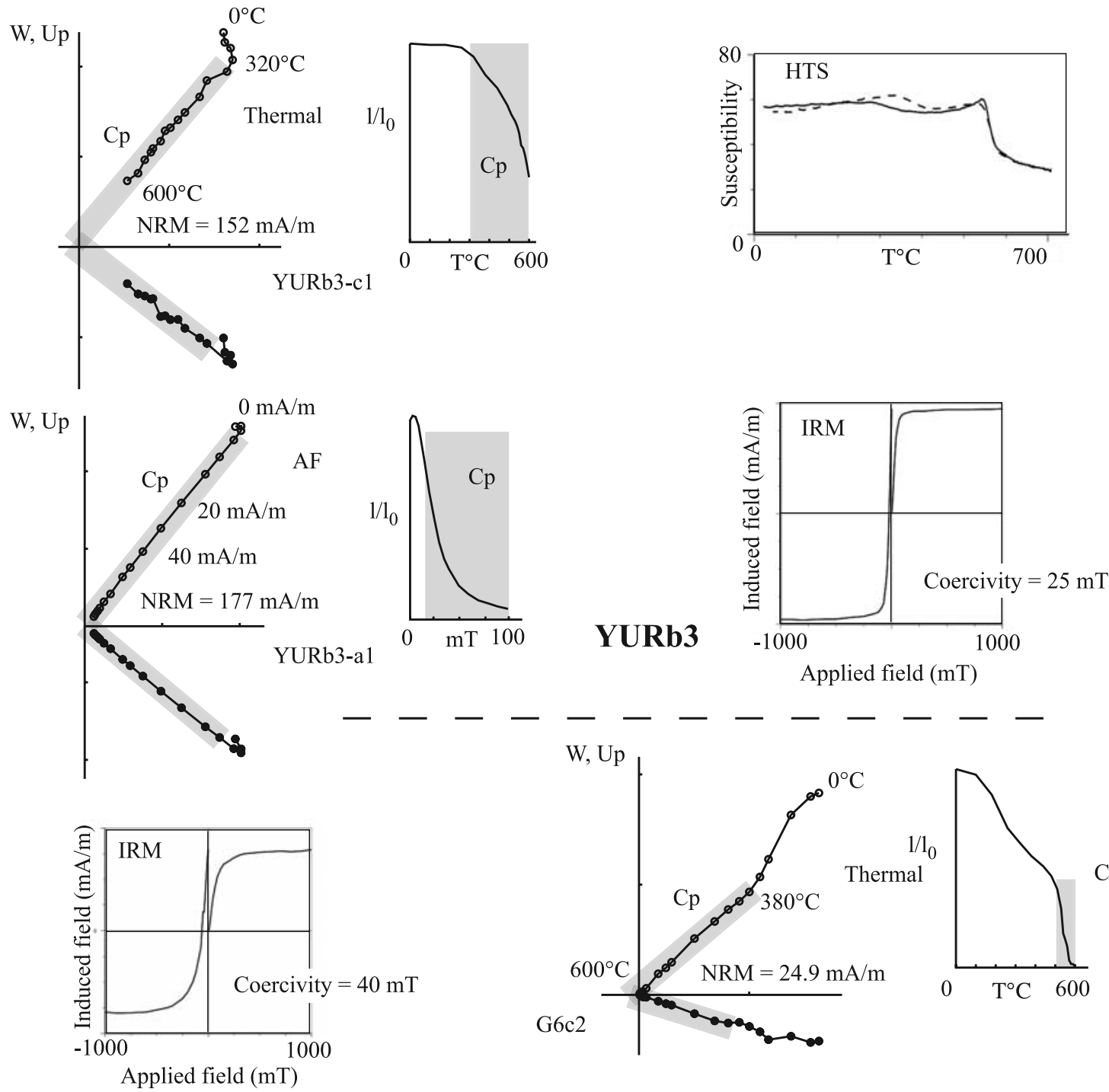

YURb3

Applied field (mT)
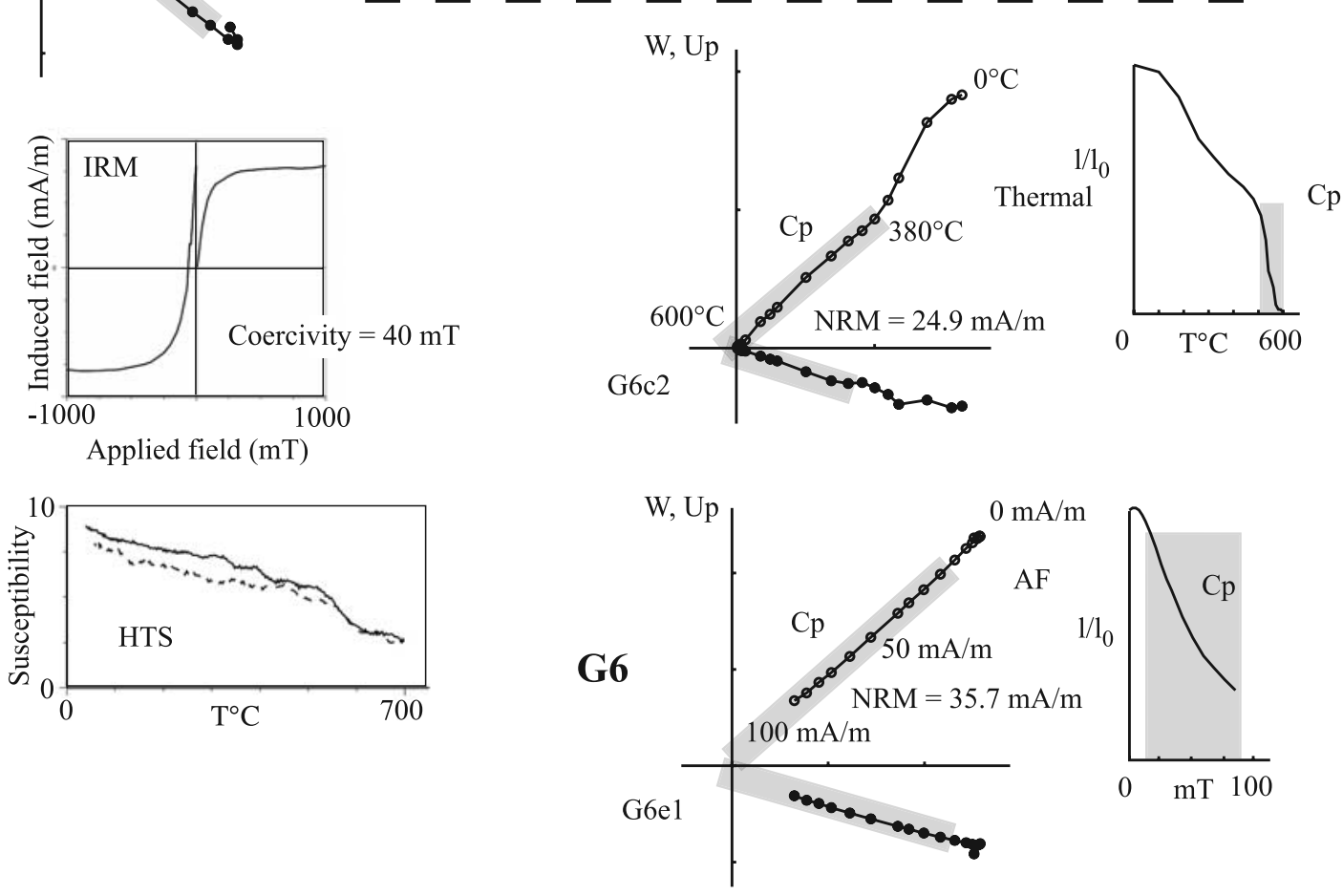

Figure 5. Demagnetization data for class A sites from the Los Frailes volcanics. Zijderveld [1967] plots (solid and open circles represent projections in the vertical and horizontal planes, respectively) and intensity plots are shown for both AF and thermal demagnetization. Also shown are the results of hightemperature susceptibility (HTS) and induced remnant magnetism (IRM) experiments. Class A sites show very well defined normal or reversed polarity high unblocking temperature components (labeled $\mathrm{Cp}$ with shading), unblocked between $\sim 450^{\circ} \mathrm{C}$ and $600^{\circ} \mathrm{C}$. IRM experiments show saturation is reached by $300 \mathrm{mT}$, with coercivities between 20 and $80 \mathrm{mT}$. All observations are consistent with $\mathrm{Cp}$ being carried by magnetite. 

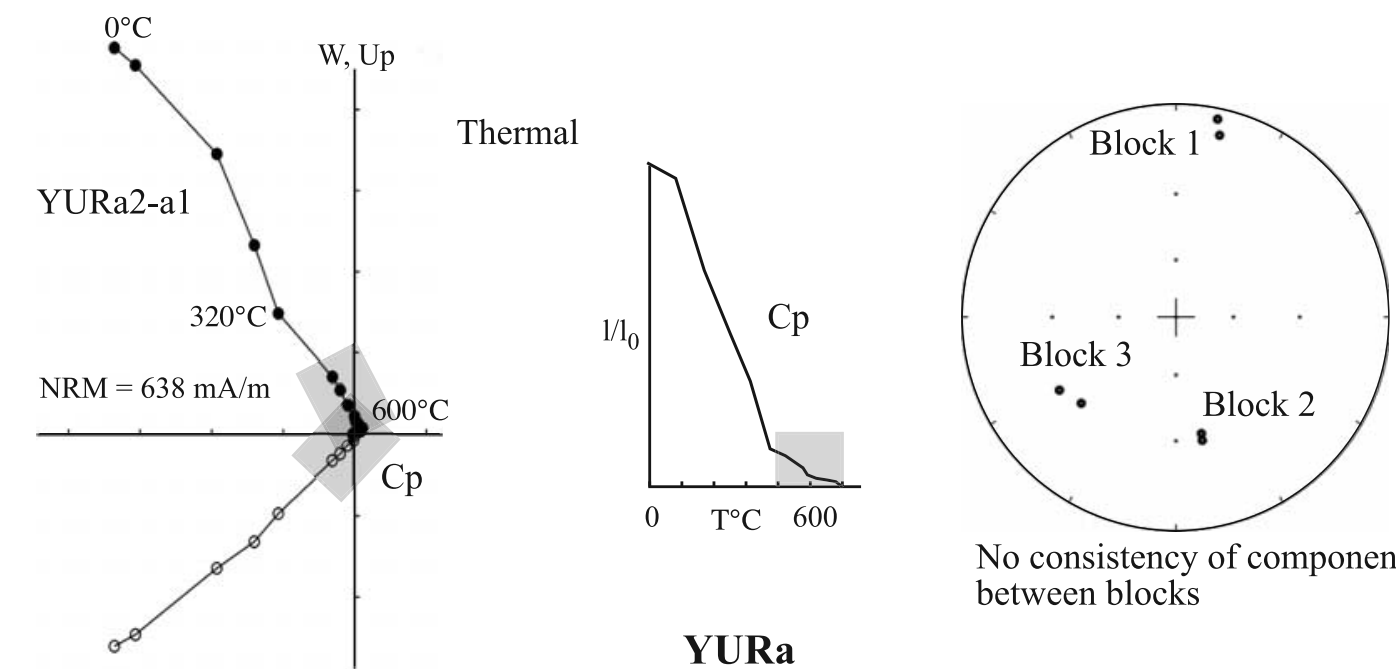

No consistency of components between blocks

YURa

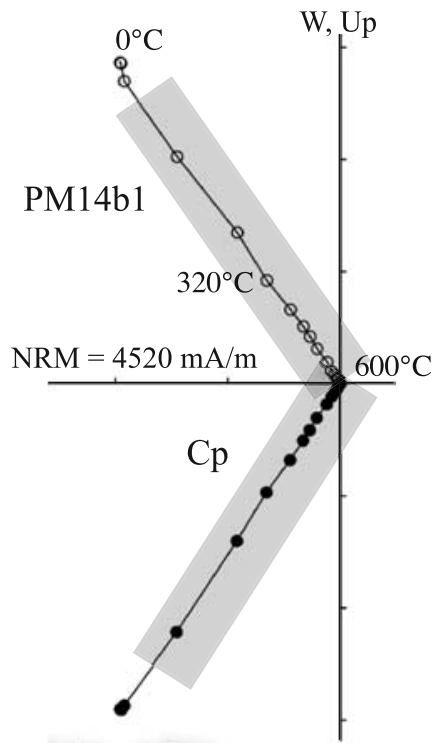

Thermal
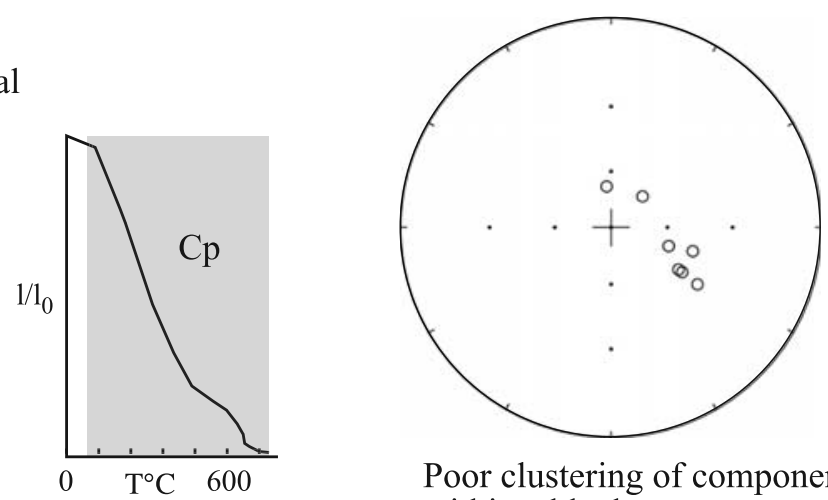

Poor clustering of components within a block

\section{PM14}

Figure 6. Demagnetization data for class B sites from the Los Frailes volcanics. Thermal demagnetization Zijderveld [1967] (solid and open circles represent projections in the vertical and horizontal planes, respectively) and intensity plots for two class B sites. Equal-area stereonets show the $\mathrm{Cp}$ directions for each specimen analyzed in the site (solid and open circles represent positive and negative inclinations, respectively). Class B sites are typically thermally soft and do not give consistent component directions and consequently their site-mean directions are not included in the final VGP estimation. In YURa, there is consistency within blocks but no consistency between the blocks. PM14, a one block site, shows very poor grouping of the principal component.

cold, with the random directions reflecting the random orientation of the magnetized grains, cannot be ruled out.

\subsubsection{Lightning Strikes}

[26] Lightning is interpreted to have struck three of the block samples analyzed in the Los Frailes volcanic complex (PORd2, PM16, VENa3). The NRM of specimens struck by lightning is up to 80 times higher than the other blocks (PORd2), and NRMs can vary greatly (i.e., over orders of magnitude) between specimens from the same block. As with the class B sites, specimens struck by lightning undergo significant thermal demagnetization below $500^{\circ} \mathrm{C}$. Component orientations from the blocks give either random directions within blocks, or orientations inconsistent with other blocks from the same site/flow.

\subsubsection{Mean Magnetization}

[27] The mean magnetization directions of class A sites and flow units are listed in Table 3. Figure 7 shows stereographic projections of mean flow unit magnetization directions, for a grouping of all the volcanics (13-2 Ma, Figures $7 \mathrm{a}, 7 \mathrm{~b}$, and $7 \mathrm{c})$, or only Miocene (13-5 Ma) volcanics (Figures $7 \mathrm{~d}$ and 7e). The flow unit means cluster into normal and reversed polarity antiparallel groups (Figures $7 \mathrm{a}$ and $7 \mathrm{~d}$ ). Mean directions from flow units YOCd and YOCe lie away from these groups (Figure 7a). 
(a)

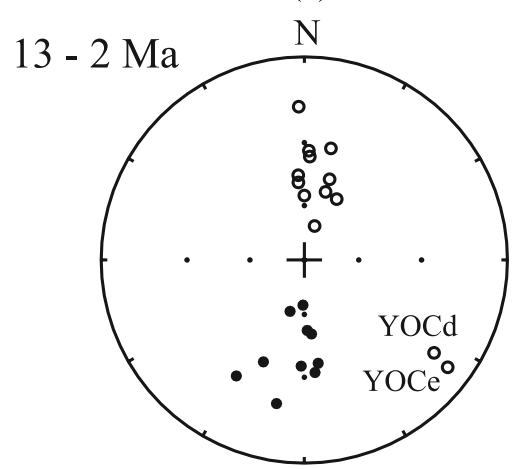

(b)

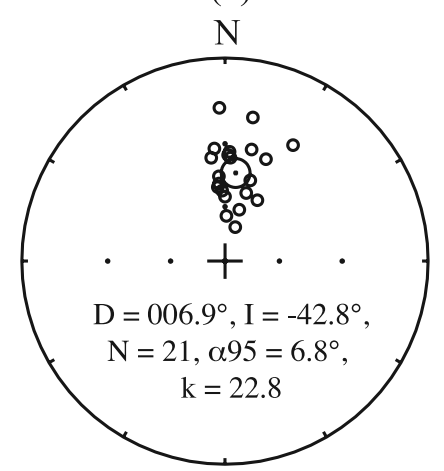

(d)

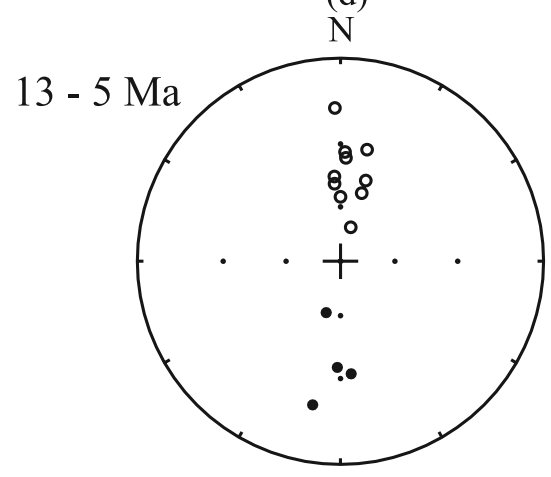

(c)

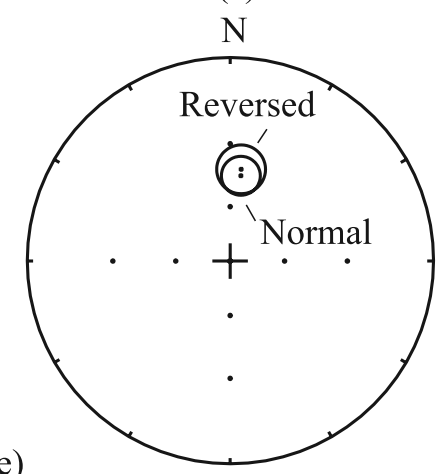

(e)

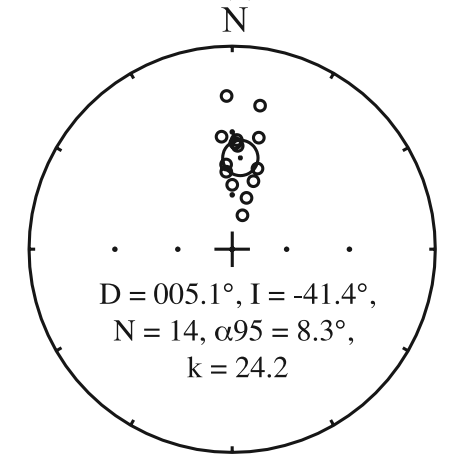

Figure 7. Flow unit paleomagnetic results for the Los Frailes volcanics, shown as equal-area stereonet projections of primary magnetization directions, with solid and open circles representing positive and negative inclinations, respectively. (a) All flow units (13-2 Ma, 21 sites, see Table 3). YOCd and YOCe are outliers. (b) All flow units except YOCd and YOCe, and with reversed polarity means inverted. The flow unit means show a clear elliptical distribution, consistent with a circular distribution for the equivalent virtual geomagnetic poles. (c) Reversals test for all flow units (ignoring YOCd and YOCe), showing the overlapping 95\% confidence limits for both reversed and normal means. (d) Miocene (13-5 Ma, 14 sites, see Table 3) flow units. (e) Miocene flow units, with reversed polarity means inverted. Again, these show a clear elliptical distribution, consistent with a circular distribution for the equivalent virtual geomagnetic poles.

These two flows outcrop together in a single $\sim 150 \mathrm{~m}$ long road cutting, with YOCe flow filling an erosional depression cut directly into YOCd flow: The reason for the directions of magnetization in these rocks is unclear, but it is possible that they record the geomagnetic field either during a reversal or when there was a highly significant nondipolar component to the field.

\subsection{Demagnetization of Morococala and Eucalyptus Volcanics}

[28] The paleomagnetic results from the Morococala and Eucalyptus volcanic complexes are listed in Table 4. The sampled flows have either been radiometrically dated directly or are stratigraphically very close to dated flows (Table 4). Examples of demagnetization and rock magnetic behavior are shown in Figure 8.

\subsubsection{Morococala Volcanics}

[29] The nine paleomagnetic sites sampled in the Morococala ignimbrites all display very similar demagnetization behavior to the Los Frailes class A sites. The NRM intensities vary from $2 \mathrm{~mA} \mathrm{~m}^{-1}$ (PM1) to $2000 \mathrm{~mA} \mathrm{~m}^{-1}$ (PM4), and $>95 \%$ of the magnetization was unblocked by $580^{\circ}$ (Figure 8 ). Both IRM acquisition and high-temperature susceptibility experiments indicate that magnetite is the principal remanence carrier. As with the Los Frailes class A sites, there is an occasional low-temperature secondary overprint. This, however, is removed by $200^{\circ} \mathrm{C}$, with approximately $75 \%$ of the NRM composed of just the principal component.

[30] All sites within the Morococala volcanic complex are one-block sites, and so it is not possible to compare block means from the same site. The specimen means cluster well, with all $\alpha_{95}$ values less than $10^{\circ}$ (with the exception of PM7, with an $\alpha_{95}$ of $11.5^{\circ}$ ). Sites from the same flow unit have the same polarity and similar orientations. Mean $\alpha_{95}$ are high for three of the flows (JAP-PM1, PM8/9-10, HUAPM6); this reflects the fact that only two sites are being averaged in each case, though the reason for the actual discrepancies between sites is unclear. Again, it is likely that the ignimbrites were emplaced at temperatures above the blocking temperatures of the magnetite grains.

\subsubsection{Eucalyptus Volcanics}

[31] Consistent principal components were only identified in three of the seven flow units sampled. The failure of the other sites can be attributed to either intense weathering of samples (SOLa, LAUa and RODa) or lightning strikes 

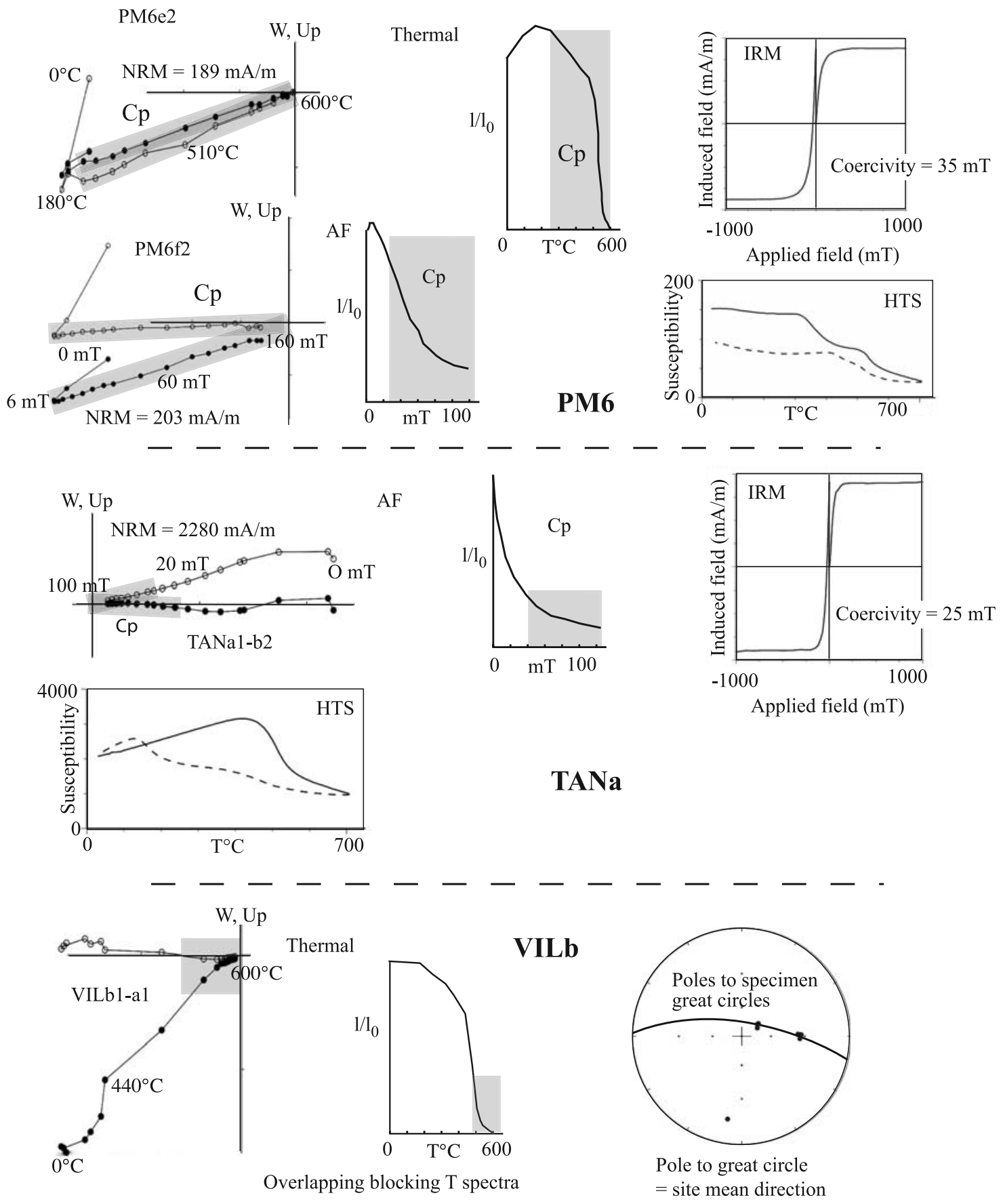

Figure 8. Demagnetization data for class A sites from the Morococala and Eucalyptus volcanics. Zijderveld [1967] (solid and open circles represent projections in the vertical and horizontal planes, respectively). Intensity plots are shown for AF and thermal demagnetization. Also shown are the results of high-temperature susceptibility (HTS) and induced remnant magnetism (IRM) experiments. These sites show very well defined normal or reversed polarity high unblocking temperature components (labeled $\mathrm{Cp}$ with shading), unblocked between $\sim 300^{\circ} \mathrm{C}$ and $600^{\circ} \mathrm{C}$. IRM experiments show saturation is reached by $300 \mathrm{mT}$, with coercivities between 20 and $80 \mathrm{mT}$. All observations are consistent with $\mathrm{Cp}$ carried by magnetite. The site-mean direction of VILb was determined using great circle analysis due to overlapping blocking spectra.

(VILc). The three sites that did produce consistent remanence orientations are all mafic shoshonitic lavas, and example demagnetization and rock magnetism curves are shown in Figure 8. The intensity of magnetization decreases sharply between 500 and $550^{\circ} \mathrm{C}$, with $<5 \%$ remaining above $580^{\circ} \mathrm{C}$. Magnetization rises sharply in the IRM experiments, and the susceptibilities drop significantly between 500 and $600^{\circ} \mathrm{C}$; the principal remanence carrier is, therefore, again 

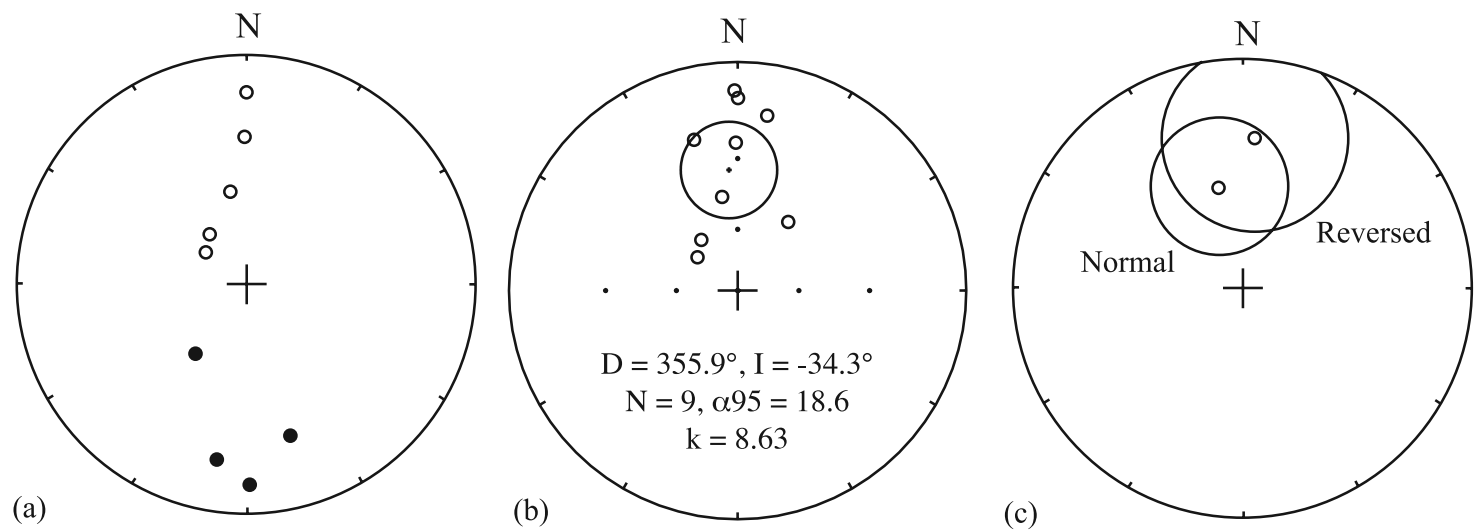

Figure 9. Flow unit paleomagnetic results for the Morococala and Eucalyptus volcanics, shown as equal-area stereonet projections of primary magnetization directions, with solid and open circles representing positive and negative inclinations, respectively. (a) All flow units (13-5 Ma, 9 sites, see Table 4). (b) All flow units with reversed polarity means inverted. The flow unit means show a clear elliptical distribution, consistent with a circular distribution for the equivalent virtual geomagnetic poles. (c) Reversals test for all flow units, showing the overlapping 95\% confidence limits for both reversed and normal means.

magnetite. Specimens do not completely demagnetize with AF treatment (Figure 8, TANa), and saturation magnetization is only reached at $900 \mathrm{mT}$ for VILb, suggesting that a higher coercivity phase is present. TANa has a lowtemperature secondary overprint, that was completely removed by $300^{\circ} \mathrm{C}$. Both VILa and VILb have two hightemperature-coercivity components with overlapping spectra: The higher-temperature component was isolated using great circle analysis. The mean magnetization directions for TANa, VILa, and VILb are all well defined with $\alpha_{95}$ values less than $10^{\circ}$.

\subsubsection{Mean Magnetization Directions}

[32] The mean magnetization directions of both sites and flow units within the Morococala and Eucalyptus volcanics are listed in Table 4, and the flow unit means are shown stereographically in Figure 9.

\subsection{Paleosecular Variation and the Timing of Magnetization}

[33] It is necessary to average the magnetic fields of a series of magnetic epochs within time periods greater than about $10^{5}$ years, so that any bias as a consequence of paleosecular variation is removed. As a general rule of thumb, a minimum of 10 epochs (sites) are required.

\subsubsection{Los Frailes Volcanics}

[34] The mean magnetization direction for the Los Frailes volcanics has been determined from 21 sites or paleomagnetic epochs, spanning $\sim 11 \mathrm{Myr}$, between 13 and $2 \mathrm{Ma}$ (Figure 7b). Taken at face value, one would therefore expect paleosecular variation to have been adequately averaged out. Furthermore, the angular dispersion of the flow mean directions, $\sim 30^{\circ}$, is high enough to suggest that the Earth's magnetic field has been adequately sampled. In addition, the flow mean directions pass a reversal test (Figure 7c), providing yet more evidence that the data represent the geocentric axial dipole field on timescales much greater than that for paleosecular variation. Finally, the elliptical distribution of flow unit mean directions (Figures $7 \mathrm{~b}$ and $7 \mathrm{e}$ ) is consistent with the expected circular distribution of site mean virtual geomagnetic poles. All these observations suggest that the magnetic components isolated in this study represent a time averaged geocentric axial dipole field.

[35] Dating the acquisition of this magnetization is less straightforward. The lack of deformation of the ignimbrites in the Los Frailes volcanic complex precludes the application of a fold test. Despite this, the demagnetization and rock magnetism data for the class A samples are consistent with a moderately high temperature for the ignimbrite eruptions, so that they acquired TRM as magnetite grains cooled through their blocking temperatures. The major mechanisms for subsequent resetting of the magnetization directions are (1) reheating, leading to thermal resetting of the magnetic grains; (2) chemical reactions altering the magnetic composition of the sample, such as surface weathering or percolating waters; and (3) lightning strikes. The units have not been reheated because they have remained at or close to the surface since eruption, and thus mechanism 1 can be ruled out. Furthermore, the effects of lightning strikes are very conspicuous (discussed above) in the data set and have not been included in the final mean flow directions. This leaves only chemical alteration, either through surface weathering or percolating groundwater, as the only possible source for remagnetization. The class B samples (usually collected from natural exposures) are, in general, the most weathered samples. Therefore it can be concluded that surface weathering has had the effect of randomizing the magnetization direction. Presumably, then, samples that do not have random directions and are not so weathered, such as the class A samples, are unlikely to have had their magnetizations reset.

[36] Another argument that the magnetization is primary and not a later overprint stems from the fact that units in contact with each other have opposite polarities. For example, sites YOCa and YOCb outcrop in the same $100 \mathrm{~m}$ long road cutting, with the contact between $\mathrm{YOCb}$ and the underlying YOCa clearly visible. They have opposite 


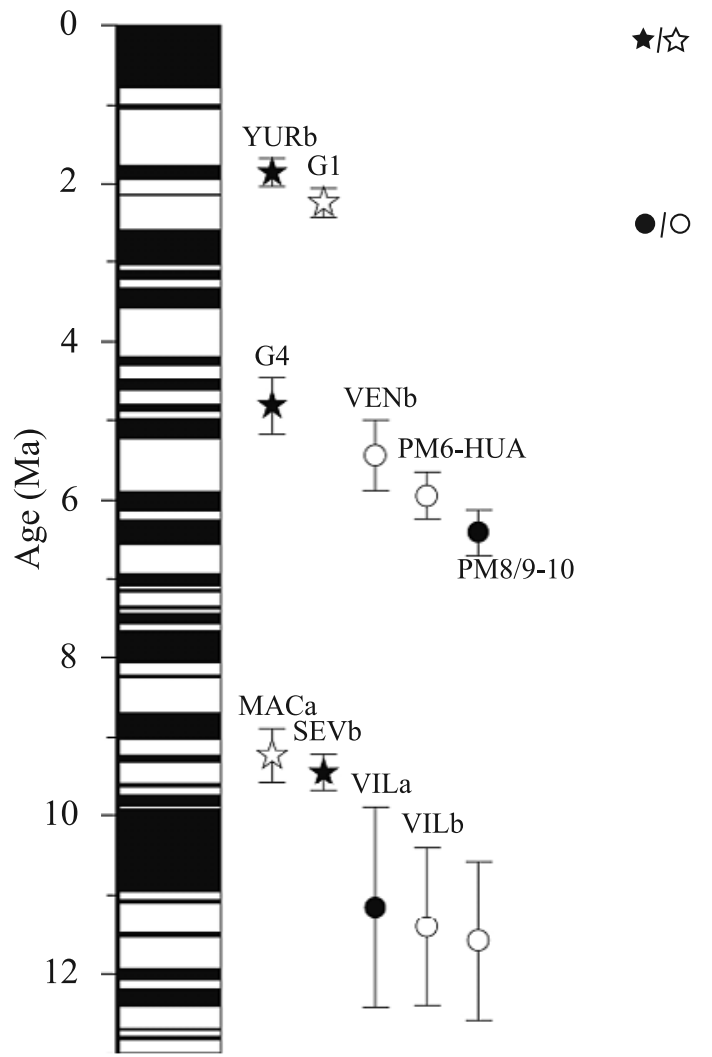

Dates of flows from Barke (2004),

black $=$ normal polarity, white $=$ reversed polarity

Dates of flows from Evernden et al. 1977,

Baker and Francis, 1978, Grant et al. (1979),

Schneider (1985), Kennan et al. (1995),

black $=$ normal polarity, white $=$ reversed polarity

Magnetization agrees with GPTS
YURb
G1
G4
VENb
MACa - on boundary
PM8/9-10
VILb

Magnetization disagrees with GPTS

$\mathrm{SEVb}$

PM6-HUA

VILa

Figure 10. Comparison of flow magnetization with the Global Polarity Timescale (GPTS) for the Los Frailes, Morococala, and Eucalyptus volcanics. GPTS is from Cande and Kent [1995]. Circles and stars refer to individual flows sampled in this study (open, normal; solid, reversed magnetization). Stars indicate Ar-Ar biotite ages from Barke [2004]; see Table 2. Circles denote published ages for stratigraphically equivalent volcanics (Tables 3 and 4).

polarities, so if there had been any resetting by reactions with percolating water, then it is surprising that both units were not reset.

[37] Finally, the magnetization of dated flows can be compared with the global polarity timescale (Figure 10). For the Los Frailes volcanics, six paleomagnetically sampled flow units have been dated directly [Schneider, 1985; Barke, 2004]. Either the other dates for the Los Frailes volcanics are not from the exact same flows as those sampled in this study, or they have high, or unspecified, errors. Although the error bars cover some reversals, five of the six flows have the magnetic polarity expected, given the mean age of the sample.

[38] The above arguments strongly suggest that class A samples have preserved their primary magnetization, acquired as the units cooled below the blocking temperatures of magnetite. Thus the mean directions represent the Earth's geocentric axial dipole field at the Los Frailes locality over the period of volcanic activity.

\subsubsection{Morococala and Eucalyptus Volcanics}

[39] Only nine flow units from the Morococala and Eucalyptus volcanics were sampled, possibly accounting for the fact that the $\alpha_{95}\left(19^{\circ}\right)$ for the mean direction is rather high (Figure 9b). If this magnetization is primary (see following discussion), then the geomagnetic field over a time span of $\sim 8$ Myr has been sampled, and one might expect paleosecular variation to be adequately averaged. Indeed, despite the high scatter in the data, the elliptical distribution of flow unit mean directions (Figure 9c), translating into a circular distribution for the equivalent virtual geomagnetic poles, supports this conclusion. In addition, the flow unit mean directions pass a reversal test (Figure 9c). However, the fact that such a high scatter in flow unit mean directions is not observed in the essentially contemporaneous and geographically close Los Frailes complex, makes the Morococala and Eucalyptus results puzzling. Perhaps some of the flow units here (and there are only nine) did, in fact, sample the field at times of significant nondipolar moments, or during reversals. Alternately, as there is no evidence that they have been disturbed since their formation, the eruptions were at relatively low temperatures and therefore there is some mechanical dispersal of magnetism.

[40] The problems encountered when trying to determine the age of magnetization for the Los Frailes volcanics appear again when dealing with the Morococala and Eucalyptus volcanic complexes. The Morococala volcanics, as already described in Section 2.2, are very similar to the Los Frailes volcanics in terms of lithology, geological setting, eruptive style and posteruption geological history. Reversals are observed within the Morococala volcanics, ruling out widespread synchronous resetting of the magnetization. 
Table 5. Bulk Tectonic Rotations With Respect to Stable South America

\begin{tabular}{|c|c|c|c|c|c|c|c|c|c|}
\hline $\mathrm{Ag}$ & $\mathrm{N}^{\mathrm{a}}$ & $\begin{array}{l}\mathrm{D}{ }^{\mathrm{b}} \\
\mathrm{deg}\end{array}$ & $\begin{array}{l}\mathrm{I}^{\mathrm{b}}{ }^{\mathrm{deg}}\end{array}$ & $\mathrm{k}^{\mathrm{b}}$ & $\begin{array}{l}\alpha_{95}{ }^{b} \\
\text { deg }\end{array}$ & $\begin{array}{l}\mathrm{R},{ }^{\mathrm{c}} \\
\mathrm{deg}\end{array}$ & $\begin{array}{c}\Delta \mathrm{R}^{\mathrm{c}}{ }^{\mathrm{deg}} \\
\end{array}$ & c & $\Delta \mathrm{F}^{\mathrm{c}}$ \\
\hline \multicolumn{10}{|c|}{ Los Frailes Volcanics $\left(19.5^{\circ} \mathrm{S}, 66.25^{\circ} \mathrm{W}\right)$} \\
\hline & 14 & & & & & 8 & 9 & & \\
\hline & 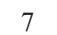 & & & 19 & 14 & & 16 & & 1 . \\
\hline & 2 & 006.9 & -42.8 & 22.8 & 6.8 & 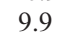 & 7.7 & -2.8 & \\
\hline
\end{tabular}

Morococala-Eucalyptus Volcanics $\left(17.75^{\circ} \mathrm{S}, 67.25^{\circ} \mathrm{W}\right)$

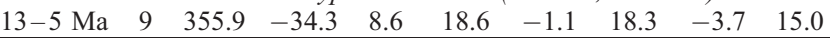

${ }^{\mathrm{a}}$ Number of paleomagnetic sites. Each site is assumed to sample the instantaneous geomagnetic field.

${ }^{\mathrm{b}} \mathrm{D}$, declination; I, inclination; $\mathrm{k}$, Fisher precision parameter, and $\alpha_{95}$ for cone of confidence, of mean magnetic vector for all sites.

${ }^{\mathrm{c}} \mathrm{R}$, rotation; F, flattening with respect to Besse and Courtillot's [2002] $10 \mathrm{Ma}$ (averaged over $20 \mathrm{Ma}$ window) South American reference pole, except for Los Frailes grouping in age range 5-2 Ma which is with respect to geographic north. Positive $\mathrm{R}$ is for clockwise rotation. $\Delta \mathrm{R}$ and $\Delta \mathrm{F}$ are $95 \%$ uncertainty limits in $\mathrm{R}$ and $\mathrm{F}$, calculated using the method of Demerest [1983].

${ }^{\mathrm{d}} \mathrm{R}$ and $\mathrm{F}$ calculated with respect to geographic north.

Also, like the Los Frailes volcanic complex, the units have remained at the surface and so have not been reheated, and lightning strikes are conspicuous. Therefore, given the similarities with the Los Frailes volcanic complex, and that the nine sites in the Morococala have the same paleomagnetic characteristics as the class A sites in the Los Frailes complex, it is reasonable to suggest that the principal magnetization is primary.

[41] In the Eucalyptus region, only the mafic shoshonitic lavas at sites VILa, VILb and TANa yielded consistent directions. The lavas at these three sites are very fine grained and indurated and there is little evidence of weathering. They have not been affected by lightning strikes (unlike site VILc) and have not been buried, and they are not all of the same polarity.

[42] A comparison of the magnetization for dated flows [Schneider, 1985; Kennan et al., 1995] with the global polarity timescale is shown in Figure 10. This comparison is inconclusive, with two flows having the expected magnetization, and two flows having different magnetizations, though the error bars are relatively large and span a range of reversals. Given all the above arguments, however, we conclude that observed magnetizations are most likely primary.

\section{Late Cenozoic Tectonic Rotation}

\subsection{South American Paleomagnetic Reference Poles}

[43] The motion of the South American plate since the early Mesozoic has been predominantly east-west, accommodating the opening of the Atlantic Ocean, and thus in all published apparent polar wander paths (APWPs) the pole remains close to the present geographic axis. However, because we are anticipating relatively small tectonic rotations in this study $\left(<20^{\circ}\right)$, it is essential to consider the APWPs for South America in more detail.

[44] Various authors have derived Cenozoic magnetic poles for the South American plate [Roperch and Carlier, 1992; Lamb and Randall, 2001; Besse and Courtillot, 2002]. The derived pole positions for the period 20 to $0 \mathrm{Ma}$ hardly vary at all between these determinations. We adopt the $10 \mathrm{Ma}$ reference pole $\left(85.9^{\circ} \mathrm{N}, 159^{\circ} \mathrm{E}, \mathrm{A} 95=2^{\circ}\right)$, determined by Besse and Courtillot [2002] from an average

Table 6. Rotation and Shortening Data Used to Constrain the Kinematics of Rotation in the sub-Andean Zone and Eastern Cordillera ${ }^{\mathrm{a}}$

\begin{tabular}{|c|c|c|c|c|c|c|}
\hline Location $^{\mathrm{b}}$ & Zone $^{\mathrm{c}}$ & Age, $\mathrm{Ma}$ & Distance North of $23^{\circ} \mathrm{S}, \mathrm{km}$ & Rotation, ${ }^{\mathrm{d}}$ deg & $\sigma{ }^{\mathrm{d}} \mathrm{deg}$ & Reference \\
\hline Lomo Blanca mine (15) & $\mathrm{P}$ & 7 & -11 & 3.5 & 5.6 & after Prezzi and Alonso [2002 \\
\hline Morro Blanco (16) & $\mathrm{P}$ & 10 & 0 & -0.9 & 1.9 & after Prezzi and Alonso [2002] \\
\hline Tiomayo (17) & $\mathrm{P}$ & 13.5 & 55 & 4.1 & 2.8 & after Prezzi and Alonso [2002 \\
\hline Lipiyoc (18) & $\mathrm{P}$ & 9 & 55 & 3.3 & 3.5 & Somoza et al. [1999] \\
\hline Bermejo (20) & SA & $15-25$ & 66 & 37.3 & 8.5 & $\operatorname{Lamb}[2001 \mathrm{a}]$ \\
\hline Rinconada (14) & $\mathrm{P}$ & 13 & 66 & 7.0 & 4.0 & after Prezzi and Alonso [2002 \\
\hline Quebrada Honda (9) & $\mathrm{EC}$ & $12-13$ & 110 & 20.3 & 1.9 & MacFadden et al. [1990] \\
\hline Monteagudo (19) & SA & $15-25$ & 275 & 7.2 & 2.8 & $\operatorname{Lamb}[2001 \mathrm{a}]$ \\
\hline Los Frailes (8) & $\mathrm{EC}$ & $5-13$ & 385 & 9.0 & 3.2 & this study \\
\hline Oroclinal axis & - & - & 550 & 0.0 & 0.5 & \\
\hline Location $^{\mathrm{b}}$ & Zone $^{\mathrm{c}}$ & Age, Ma & Distance North of $23^{\circ} \mathrm{S}, \mathrm{km}$ & Shortening, km & $\sigma, \mathrm{em}$ & Reference \\
\hline$\sim 22.5^{\circ} \mathrm{S}$ & SA & $0-15$ & 55 & 60 & 15 & Echavarria et al. [2003] \\
\hline$\sim 22.5^{\circ} \mathrm{S}$ & SA & $0-15$ & 55 & 60 & 15 & Mingramm et al. [1979] \\
\hline$\sim 22.5^{\circ} \mathrm{S}$ & SA & $0-15$ & 55 & 53 & 15 & Schmidtz and Kley [1997] \\
\hline$\sim 22^{\circ} \mathrm{S}$ & SA & $0-15$ & 110 & 100 & 15 & Dunn et al. [1995] \\
\hline$\sim 21.5^{\circ} \mathrm{S}$ & SA & $0-15$ & 165 & 86 & 15 & Baby et al. [1997] \\
\hline $20.5-20^{\circ} \mathrm{S}$ & SA & $0-15$ & 330 & 73.5 & 5 & this study \\
\hline$\sim 19.5^{\circ} \mathrm{S}$ & SA & $0-15$ & 385 & 67 & 15 & McQuarrie [2002] \\
\hline$\sim 17.5^{\circ} \mathrm{S}$ & SA & $0-15$ & 605 & 110 & 15 & Sheffels [1990] \\
\hline
\end{tabular}

${ }^{\mathrm{a}}$ See Figure 11.

${ }^{\mathrm{b}}$ With reference in Table 1 and Figure 1.

${ }^{\mathrm{c}} \mathrm{A}$, Altiplano; P, Argentine Puna; EC, Eastern Cordillera; SA, sub-Andean zone.

${ }^{\mathrm{d}}$ Rotations are with respect to the South American reference pole used by Barke [2004], which is a more conservative estimate and is the mean of five Late Cenozoic reference poles (in the time frame 0-25 Ma) from Roperch and Carlier [1992], Lamb and Randall [2001], Besse and Courtillot [2002]. These rotations are within $1^{\circ}$ of those calculated using the 10 Ma pole (20 Ma window) of Besse and Courtillot [2002]; $\sigma$, estimate of standard deviation $\left(0.4 \alpha_{95}\right)$.

${ }^{\mathrm{e} E s t i m a t e d ~ s t a n d a r d ~ d e v i a t i o n ~ f o r ~ s h o r t e n i n g ~ e s t i m a t e . ~}$ 
(a)

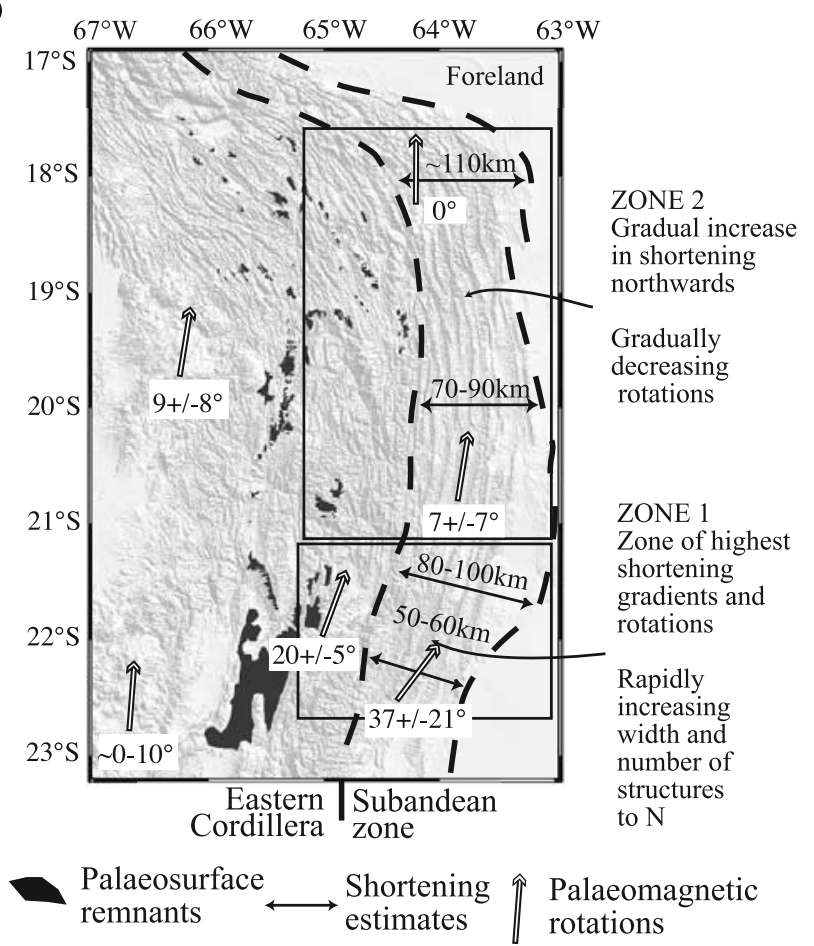

(b)

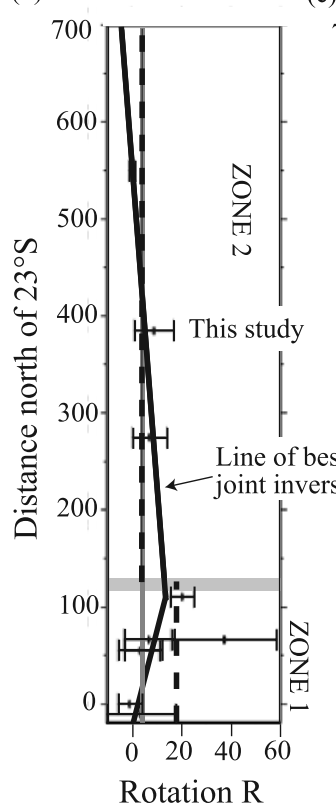

(o) (c)

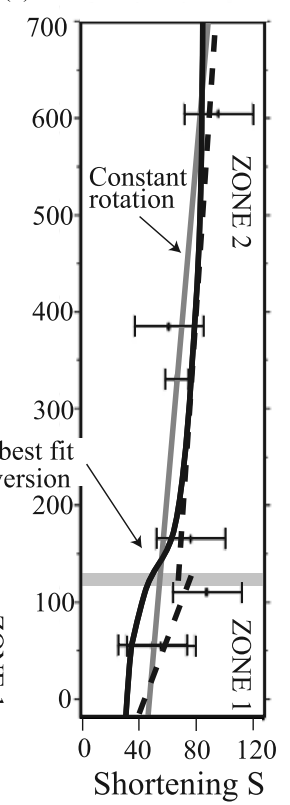

(km)

Figure 11. Kinematic interpretation of rotations in the Eastern Cordillera (see Table 6). (a) Map of the eastern central Andes, showing late Miocene paleosurface remnants (black patches), published rotations and shortening estimates. Rotations and shortening can be divided into two zones (1 and 2). In zone 1, large shortening gradients and rotations increase northward; in zone 2, there are lower shortening gradients and rotations decrease northward. (b) Published paleomagnetically determined rotations for the Bolivian Andes, with various model fits. Solid horizontal gray line shows rotation accommodated by average shortening gradients along the length of the sub-Andean zone (see solid sloping gray line in Figure 11c). Dashed line shows rotation accommodated by average shortening gradients along the subAndean zone in zones 1 and 2 (see dashed lines in Figure 11c). Sloping solid black line shows best fit model based on a joint inversion of both paleomagnetic and shortening dating, assuming rotation varies linearly in zones 1 and 2 (see text for details). (c) Published shortening estimates along the length of the sub-Andean zone, with various model fits. Sloping gray line shows average shortening gradient, whereas dashed lines show shortening gradients in zones 1 and 2. Sloping solid black line shows best fit model based on a joint inversion of both paleomagnetic and shortening data.

of poles over the last $20 \mathrm{Myr}$, as the best estimate of the reference pole for the 13-2 Ma volcanics analyzed in this study (Tables 3 and 4).

\subsection{Bulk Tectonic Rotations}

[45] Table 5 lists the rotations and flattenings calculated for the northern (Morococala and Eucalyptus complexes) and southern (Los Frailes complex) volcanic provinces, based on the mean magnetization directions determined in this study. The associated $95 \%$ confidence limits are determined using the technique of Demerest [1983], incorporating the $\alpha_{95}$ of the observed magnetizations and the A95 error in the reference pole.

[46] We begin by considering the null hypothesis that there has been no tectonic rotation. In this case, we would expect the mean of all the data to lie within the confidence limits of the direction predicted by the reference pole. The Los Frailes volcanic complex (for 21 sites) fails the null hypothesis, showing a significant clockwise rotation $\mathrm{R}$ of $10^{\circ} \pm 8^{\circ}$ at the $95 \%$ confidence level (Table 5). The errors for the Morococala and Eucalyptus volcanics (for 9 sites) are much higher than those for the Los Frailes, because of the associated high $\alpha_{95}$ value for the mean magnetization direction. Therefore, at the $95 \%$ confidence level, the Morococala and Eucalyptus volcanics are consistent with the null hypothesis $\left(\mathrm{R}=-1^{\circ} \pm 18^{\circ}\right)$, though the mean rotation tentatively suggests that there has been some differential rotation between the northern and southern limbs of the Bolivian orocline, even if the rotations have not necessarily had opposing senses.

[47] Given that the Los Frailes volcanic complex fails the null hypothesis, we can consider more restricted age groupings of the data. Thus the Miocene (13-5 Ma) Los Frailes volcanics (14 sites) show a rotation $\mathrm{R}$ of $8^{\circ} \pm 9^{\circ}$, whereas the Plio-Pleistocene (5-2 Ma) Los Frailes volcanics (7 sites) show a rotation of $11^{\circ} \pm 17^{\circ}$. For all these groupings, the 
flattening $\mathrm{F}$ is not significant at the $95 \%$ confidence level (Table 5).

\section{Rotational Kinematics}

[48] In this section, we investigate the kinematics of Late Cenozoic vertical axis rotations in the Bolivian Andes, south of the oroclinal axis, by integrating the results of this and previous paleomagnetic studies with the available Late Cenozoic tectonic shortening estimates in the Eastern Cordillera and sub-Andean zone (Figure 1).

\subsection{Late Cenozoic Deformation in the Bolivian Eastern Cordillera and sub-Andean Zone}

[49] Well-preserved geomorphic surfaces and stratigraphic sequences, dated between $\sim 9$ and $12 \mathrm{Ma}$ (from Ar-Ar ages on biotite in tuffs that either mantle or underlie the surfaces [Gubbels et al., 1993; Kennan et al., 1995; Barke, 2004]), suggest that there has been negligible compressional (or extensional) folding and faulting in the Bolivian Eastern Cordillera in the last $\sim 12 \mathrm{Myr}$ [Gubbels et al., 1993; Kennan et al., 1995; Lamb et al., 1997; Kennan et al., 1997; Lamb, 2000, 2001b; Barke, 2004]. Deformation is limited to strikeslip faulting, which is active today [Kennan, 1994; Lamb, 2000; Barke, 2004; Funning et al., 2005], or rare normal faulting with vertical offsets $<10 \mathrm{~m}$ [Cladouhos et al., 1994]. This faulting is particularly prominent in the hinge region of the Bolivian orocline, around Cochabamba, where both ESE trending sinistral and dextral north trending faults are observed [Kennan, 1994; Lamb, 2000; Funning et al., 2005]. However, pervasive conjugate sinistral and dextral strike-slip faulting occur on the southern limb of the Bolivian orocline, throughout the Eastern Cordillera and western margin of the sub-Andean zone [Lamb, 2000; Barke, 2004], though most offsets appear to predate the $\sim 9$ Ma geomorphic surfaces in the Eastern Cordillera [Barke, 2004]. All this suggests that there has been negligible dilation in the Eastern Cordillera in the last $\sim 12 \mathrm{Myr}$, as is also the case in the Los Frailes and Morococala complexes on the western margin of the Eastern Cordillera.

[50] In the Bolivian sub-Andean zone, on the southern limb of the Bolivian orocline, late Miocene to Pliocene red bed sequences, up to $5 \mathrm{~km}$ thick, are preserved in the cores of tight synclines. Detailed studies of the stratigraphy here have shown that rapid sedimentation began in the late Miocene, between $\sim 15$ and $\sim 9 \mathrm{Ma}$, with the subsequent development of a thin-skinned fold and thrust belt [Echavarria et al., 2003; Uba et al., 2005]. Balanced cross sections show that the finite shortening ranges between $\sim 50$ and $\sim 110 \mathrm{~km}$ (see Table 6 and references therein).

[51] If we can find a self consistent model of rotation and strain in the Eastern Cordillera and sub-Andean zone, we should be able to reduce the uncertainties in the timing and amount of both rotation and strain. Thus Lamb [2001b] attempted to formally invert for the full finite strain field during the last $10 \mathrm{Myr}$ in a network of triangles covering the Eastern Cordillera. Despite the large uncertainties in the available input strain data, the inversion clearly showed that tectonic rotations here, with respect to stable South America, reflect, to first order, shortening gradients along the length of the sub-Andes [Lamb, 2000, 2001b], and strike-slip faulting within the Eastern Cordillera accommodates internal strain as a consequence of the bending of the Eastern Cordillera.

[52] In the following analysis, we use a simplified version of the approach of Lamb [2001b], making use of new estimates of both rotation and shortening [this study, Prezzi and Alonso, 2002; McQuarrie, 2002; Echavarria et al., 2003; Barke, 2004]. Given that the time frame for Late Cenozoic rotation and deformation in the Eastern Cordillera and sub-Andean zone is similar, we begin by assuming that all observed rotation and shortening is synchronous. We can, then, test this assumption by searching for discrepancies between observed and predicted deformation.

\subsection{Kinematics of Late Cenozoic Vertical Axis Rotation and Shortening}

[53] If Late Cenozoic vertical axis rotation in the Eastern Cordillera and sub-Andean zone is accommodated by gradients of shortening along the length of the sub-Andean zone, then observations of both can be expressed, to first approximation, as follows:

$$
\tan R=\frac{d S}{d x}
$$

where $\mathrm{R}$ is the vertical axis rotation, $\mathrm{S}$ is shortening in the sub-Andean zone, and $\mathrm{x}$ is distance parallel to the strike of the sub-Andean zone. Paleomagnetically determined rotations for the Eastern Cordillera and sub-Andean zone, together with shortening estimates in the sub-Andean zone, are summarized in Table 6 and are plotted in Figure 11. The rotation data for the sub-Andean zone are from localities at the back of the fold and thrust belt, on the western margin of the sub-Andes. For this reason, these localities essentially record any rotation accommodated by deformation in the sub-Andean zone, farther east.

[54] Simple fits to the gradient of shortening along the length of the sub-Andean zone (Figure 11c), including or excluding possible outliers at distances $\sim 110 \mathrm{~km}$ and $\sim 165 \mathrm{~km}$ north of $23^{\circ} \mathrm{S}$, suggest a clockwise vertical axis rotation of the Eastern Cordillera in the range $3.2^{\circ}$ to $4.9^{\circ}$, relative to stable South America, on the southern limb of the orocline. However, a closer inspection of shortening along the length of the sub-Andean zone suggests that the largest gradients are between $23^{\circ} \mathrm{S}$ and $22^{\circ} \mathrm{S}$ (Figures 11a and 11c). In this region (zone 1), shortening increases from $50-60 \mathrm{~km}$ to up to $80-100 \mathrm{~km}$ over a distance of $50-100 \mathrm{~km}$. North of $\sim 22^{\circ} \mathrm{S}$, in zone 2 , shortening increases more gradually, up to an estimated $\sim 110 \mathrm{~km}$ at the oroclinal axis. Further evidence for this can be seen in the topography of the subAndean zone: Within zone 1, the sub-Andean zone widens northward with an increase in the number of ridges (shortening structures), whereas in zone 2 , the sub-Andean zone has an approximately constant width, but ridges gradually become more tightly spaced (Figure 11a). Thus, if gradients of shortening in zones 1 and 2 are treated separately (Figure 11c), then these suggest a clockwise rotation of $\sim 17.7^{\circ}$ for zone 1 , and $\sim 3.4^{\circ}$ farther north, in zone 2 (Figure 11b).

[55] These results are identical within error with the paleomagnetic data, which suggest higher clockwise rotations in zone 1 compared to zone 2, providing general confirmation that the amount of shortening in the sub- 
Andean zone is of the right magnitude to accommodate the rotation of the Eastern Cordillera, and observed rotation and sub-Andean shortening are essentially synchronous, occurring in the last 10 to 15 Myr. Thus vertical axis rotation of the Los Frailes volcanics in this period is predicted to be at the lower end ( $3^{\circ}$ to $5^{\circ}$ clockwise) of the paleomagnetically determined uncertainty limits, in marked contrast to the suggestion of Richards et al. [2004], who proposed $\sim 18^{\circ}$ of clockwise rotation on the southern limb of the Bolivian orocline in the last $10 \mathrm{Myr}$, based mainly on an analysis of Mesozoic and Paleogene paleomagnetic data.

[56] An even closer inspection of the paleomagnetic rotation data in the Eastern Cordillera suggests that the magnitude of rotation varies more-or-less linearly, increasing northward in zone 1, and then decreasing northward in zone 2; the rotation must be zero in the hinge of the orocline itself. In addition, Lamb [2001a] showed that there was a $1: 1$ relation between the magnitude of paleomagnetically determined rotation along the length of the western margin of the sub-Andean zone and the strike of fold and fault structures, suggesting that the curvature of the sub-Andean zone is a consequence of tectonic rotation. In the following analysis, we explore further these smooth variations in rotation in the Eastern Cordillera with a simple kinematic model, as well as combining shortening and rotation data together to improve the estimates of both.

\subsubsection{Joint Kinematic Inversion}

[57] We consider the simplest case, where vertical axis rotation varies linearly along the length of the Eastern Cordillera (defined by distance $\mathrm{x}$ ). Therefore the shortening in the sub-Andean zone (which is the spatial integral of rotation) must vary quadratically with distance $\mathrm{x}$ (Figures $11 \mathrm{~b}$ and $11 \mathrm{c}$ ). To allow for the change in style between zone 1 and zone 2, we specify two rotation functions (one each for zone 1 and zone 2) with the constraint that rotation and shortening at the intersection of these trends $(\mathrm{x}=\mathrm{k})$ is the same. Therefore, in this model, the rotations (R) and shortening $(\mathrm{S})$ are expressed as

$$
\begin{aligned}
& \text { For } x<k \\
& S=a_{1}(x-k)^{2}+b(x-k)+c \\
& \frac{d S}{d x}=\tan R=2 a_{1}(x-k)+b \\
& \text { For } x>k \\
& S=a_{2}(x-k)^{2}+b(x-k)+c \\
& \frac{d S}{d x}=\tan R=2 a_{2}(x-k)+b
\end{aligned}
$$

[58] There are five unknowns, $a_{1}, a_{2}, b, c$ and $k$. However, $k$ is relatively well constrained at $\sim 120 \mathrm{~km}$, because the change in style from zone 1 to zone 2 is observed in the topography, as well as by a marked change in shortening and trend of the sub-Andes (Figure 11a). Given the estimates of $R$ and $S$ along the length of the Andes (Table 6), the remaining four unknowns are solved for using a least squares matrix inversion, where the data are weighted according to the inverse of their variance. Defining $\mathbf{A}$ as the model matrix, $\mathbf{d}$ as the data, and $\mathbf{m}$ as comprising the unknown parameters, the solution is given by [Menke, 1988]

$$
\mathbf{m}=\left[\mathbf{A}^{\mathbf{T}} \mathbf{W} \mathbf{A}\right]^{-1} \mathbf{A}^{\mathbf{T}} \mathbf{W} \cdot \mathbf{d}
$$

where $\mathbf{A}^{\mathbf{T}}$ is the transpose of $\mathbf{A}$, and $\mathbf{W}$ is a square matrix with only nonzero diagonal components, which are the reciprocals of the variances of the components of $\mathbf{d}$.

[59] There are 18 data used in the inversion, making the problem substantially overdetermined (Table 6). In addition to the published shortening estimates and rotations, we impose an extra constraint that there is zero rotation at the oroclinal axis (where the sense of rotation changes sign). The standard deviations for the rotations are equal to 0.4 times the error in rotation, $\Delta R$ [Lamb and Randall, 2001]. The standard deviation for the shortening estimate presented by Barke [2004] is taken as half the range of shortening. All the previously published shortening estimates are only "preferred" solutions, and many of the studies do not focus specifically on constraining shortening in the sub-Andean zone, and in addition, the precise timing of shortening is uncertain. Therefore we allow these estimates to have a relatively high standard deviation of $15 \mathrm{~km}$.

\subsubsection{Best Fit Kinematic Model}

[60] The results of the "joint inversion" are plotted in Figures $11 \mathrm{~b}$ and $11 \mathrm{c}$. The best fitting solution yielded $a_{1}=$ $0.001, a_{2}=-0.0003, b=0.24$ and $c=47.4$. This calculation was performed with the location of the crossover point, defined by $\mathrm{k}$, fixed at a mean value of $120 \mathrm{~km}$ north of $23^{\circ} \mathrm{S}$. Solutions were actually obtained by allowing $\mathrm{k}$ to vary between 60 and $150 \mathrm{~km}$, but this results in negligible variation in the final solution.

[61] A visual inspection of Figures $11 \mathrm{~b}$ and 11c shows that the model has a good fit with the both the shortening and the rotation data. The model matches all of the rotation data within $95 \%$ confidence, with the exception of only two points, located close to the intersection point. In addition, the model fits nearly all of the shortening data within $2 \sigma$ (Figure 11c). This provides further confirmation that shortening gradients in the sub-Andean zone are primarily responsible for accommodating the pattern of Late Cenozoic rotation in the Eastern Cordillera, and all the observed shortening and rotation in this region were synchronous, occurring in the last 10 to 15 Myr. Rotation of the Eastern Cordillera, relative to stable South America, varies from zero at the oroclinal hinge, at $\sim 18^{\circ} \mathrm{S}$, reaching a maximum of $\sim 13.5^{\circ}$ clockwise at $\sim 22^{\circ} \mathrm{S}$, then decreases to zero, south of $23^{\circ} \mathrm{S}$ (Figure $11 \mathrm{~b}$ ), with shortening in the sub-Andean zone decreasing from a maximum of $\sim 86 \mathrm{~km}$ at the oroclinal hinge to $\sim 47 \mathrm{~km}$ at $22^{\circ} \mathrm{S}$ and then $\sim 33 \mathrm{~km}$ at $23^{\circ} \mathrm{S}$ (Figure $11 \mathrm{c}$ ).

\subsection{Internal Bending of the Eastern Cordillera}

[62] The spatial variation in rigid body rotations about vertical axes on the southern limb of the orocline between $\sim 23^{\circ} \mathrm{S}$ and $\sim 18^{\circ} \mathrm{S}$, with rotation increasing then decreasing toward the north (Figure 11c), requires internal faulting of the Eastern Cordillera. However, it is clear from the preservation of geomorphic surfaces that there has been no large-scale faulting here in the last $\sim 9 \mathrm{Myr}$, with mainly 
strike-slip faulting prior to this. Strike-slip deformation in the hinge of the orocline itself has clearly been active up to the present. Thus either internal bending in the Eastern Cordillera, south of the hinge, occurred mainly prior to $\sim 9 \mathrm{Ma}$, and since then, the Eastern Cordillera has rotated coherently, or faulting has occurred on too small a scale to be observed in geomorphic features. In either case, because the bending is predicted to be relatively small $\left(<10^{\circ}\right)$ for most of the region north of $\sim 22^{\circ} \mathrm{S}$, in zone 2 , any internal deformation that accommodates this will also be small, and possibly hard to detect; the main locus of deformation related to bending would be predicted to be south of $\sim 22^{\circ} \mathrm{S}$, where bending is greatest. The strain inversions of Lamb [2000, 2001b] clearly show how this can be achieved through strike-slip faulting.

[63] A change in deformational mode at $\sim 9$ Ma could be a consequence of a dramatic expansion of thin-skinned foreland shortening, so that this style of deformation extended along the entire length of the Bolivian sub-Andes, south of the oroclinal axis. Thus, prior to this, internal bending of the southern limb of the orocline might have been a consequence of a lateral transition at $\sim 22^{\circ} \mathrm{S}$ from thick-skinned shortening farther south, to thin-skinned thrusting in the north. This is because lithosphere undergoing thick-skinned shortening may have different mechanical properties to thin-skinned folding and thrusting above a well-lubricated basal decollement, and consequently could be a less efficient way of absorbing large amounts of crustal shortening [Watts et al., 1995].

\subsection{Oroclinal Bending of the Western Cordillera and Chilean Forearc}

[64] Paleomagnetic studies in the forearc region of northern Chile, at the latitudes of the Bolivian Andes, have shown that tectonic rotations about vertical axes here have been small $\left(\leq 5^{\circ}\right.$ clockwise) in the last $\sim 20 \mathrm{Myr}$ [Roperch et al., 1999, 2000; Somoza et al., 1999; Prezzi and Alonso, 2002]. Thus it is unclear whether the rotation observed in the Eastern Cordillera of Bolivia extends across the entire width of the Andes, although a forearc rotation $\leq 5^{\circ}$ is still, within error, the same as that observed in the Eastern Cordillera.

[65] If there is no rotation of the forearc, then this requires along strike gradients of shortening in the Altiplano, Western Cordillera, and Chilean forearc which are the inverse of those in the sub-Andean zone, for which there is no structural evidence. Indeed, shortening in these regions in the last $\sim 20 \mathrm{Myr}$ has been relatively small $(<30 \mathrm{~km})$, with negligible shortening in the forearc [Lamb and Hoke, 1997]. Alternatively, rotation of the trend of the forearc has been accommodated by east-west shear along strike-slip faults, without rotation of the intervening fault blocks, although evidence for the appropriate strike-slip faults, with the right sort of displacements, is so far lacking.

[66] We favor a compromise model in which some of the rotation $\left(\leq 5^{\circ}\right)$ in the Eastern Cordillera in the last 10 to $15 \mathrm{Myr}$ is absorbed by deformation in the Altiplano and Western Cordillera, and the remaining rotation is transmitted to the forearc region as a combination of rigid body rotation about a vertical axis $\left(\leq 5^{\circ}\right)$ and distributed east-west shear. However, given the paleomagnetic and structural constraints, the overall rotation of the trend of the forearc in the last $20 \mathrm{Myr}$, through a combination of shear and rigid body rotation, must be less than $10^{\circ}$ clockwise. This relatively small rotation may reflect more closely the more regional Late Cenozoic bending of the whole mountain range.

\section{Summary}

[67] 1. A paleomagnetic study of the 13-2 Ma Los Frailes volcanic complex on the southern limb of the Bolivian orocline, and on the western margin of the Eastern Cordillera, has yielded a statistically significant rigid body rotation about a vertical axis, $10^{\circ} \pm 8^{\circ}$ clockwise relative to stable South America $\left(8^{\circ} \pm 9^{\circ}\right.$ clockwise for $13-5$ Ma Los Frailes volcanics). This rotation applies, at the very least, to the area underlain by these volcanics, extending for $>7500 \mathrm{~km}^{2}$. Paleomagnetic analysis of the 13-5 Ma Morococala and Eucalyptus volcanics, on the northern limb of the orocline, suggest anticlockwise rotations, although these are not statistically significant $\left(1^{\circ} \pm 18^{\circ}\right.$ anticlockwise relative to stable South America).

[68] 2. Paleomagnetically observed vertical axis rotation in the sub-Andean zone and Eastern Cordillera is consistent with observed shortening gradients in the sub-Andean zone, suggesting rotation and shortening are synchronous, taking place in the last $10-15 \mathrm{Myr}$. The best fit average gradient of shortening along the length of the sub-Andean zone, between $\sim 23^{\circ} \mathrm{S}$ and $18^{\circ} \mathrm{S}$, accommodates $3^{\circ}$ to $5^{\circ}$ of clockwise vertical axis rotation of the Eastern Cordillera, relative to stable South America, though in detail, average rotation is higher between $\sim 23^{\circ} \mathrm{S}$ and $\sim 22^{\circ} \mathrm{S}\left(\sim 17.7^{\circ}\right.$ clockwise $)$, compared to $\sim 3.4^{\circ}$ clockwise farther north.

[69] 3. A joint inversion for both tectonic rotation and the amount of sub-Andean shortening suggests that a linear variation in the amount of rotation along the length of the southern limb of the Bolivian orocline fits both the paleomagnetic and shortening data best for the last 10-15 Myr. This shows that rotation of the Eastern Cordillera, relative to stable South America, varies from zero at the oroclinal hinge, at $\sim 18^{\circ} \mathrm{S}$, reaching a maximum of $\sim 13.5^{\circ}$ clockwise at $\sim 22^{\circ} \mathrm{S}$, then decreases to zero, south of $23^{\circ} \mathrm{S}$, with an average rotation in the range $5^{\circ}$ to $10^{\circ}$ clockwise. Concomitant with this, shortening in the sub-Andean zone decreases from a maximum of $\sim 86 \mathrm{~km}$ at the oroclinal hinge, to $\sim 47 \mathrm{~km}$ at $22^{\circ} \mathrm{S}$, and then $\sim 33 \mathrm{~km}$ at $23^{\circ} \mathrm{S}$.

[70] 4. The lack of evidence for large-scale internal faulting in the Eastern Cordillera since $\sim 9$ Ma suggests either bending of the Eastern Cordillera was accommodated by more distributed small-scale faulting, or that relative rotation here mainly occurred prior to $\sim 9 \mathrm{Ma}$. A change in style of deformation might be related to both the spatial and temporal development of thin-skinned deformation in the sub-Andean zone, which could be a mechanically more efficient mechanism than thick-skinned folding and thrusting to accommodate shortening on the eastern margin of the Andes.

[71] 5. The average rotation determined in this study for the Eastern Cordillera, on the southern limb of the orocline, is consistent with paleomagnetic evidence for only very small rotation $\left(<10^{\circ}\right)$ of the forearc region in northern Chile during the last $\sim 20 \mathrm{Myr}$, and may reflect the more regional bending of the southern limb of the orocline, with clockwise 
rotation of the trend of the entire width of the mountain chain by $5^{\circ}$ to $10^{\circ}$ in the last $10-15 \mathrm{Myr}$, accommodated by both rigid body rotation and distributed shear. During the same period, rotation of the northern limb is less well constrained, but it is also likely to be small $\left(<5^{\circ}\right)$ and anticlockwise.

[72] Acknowledgments. This work was supported by grants from NERC, Royal Society, and EU. This work was carried out during a studentship (R.B.) tied to a NERC research grant held by S. L. Ray Burgess kindly made it possible for R.B. to carry out the Ar-Ar geochronology at the Department of Earth Sciences, University of Manchester. We would like to especially thank Estela Minaya, Directora of the Observatorio San Calixto, for her help and collaboration. We also thank Gareth Funning, James and Alfredo Quisberth, and Maximo Paredes for all their help in the field. The manuscript greatly benefited from helpful reviews by Guillaume Dupont-Nivet, Randy Enkin, and an anonymous reviewer.

\section{References}

Allmendinger, R. W., B. L. Isacks, T. E. Jordan, and S. M. Kay (1997), The evolution of the Altiplano-Puna plateau of the central Andes, Annu. Rev. Earth Sci., 25, 139-174.

Baby, P., P. Rochat, G. Mascle, and G. Herail (1997), Neogene shortening contribution to crustal thickening in the back arc of the central Andes, Geology, 25, 883-886.

Baker, M. C. W., and P. W. Francis (1978), Upper Cenozoic volcanism in the central Andes, ages and volumes, Earth Planet. Sci. Lett., 41, $175-$ 187.

Barke, R. M. D. (2004), Late Cenozoic tectonic and topographic evolution of the Bolivian Andes, Ph.D. thesis, Univ. of Oxford, Oxford, U.K.

Besse, J., and V. Courtillot (2002), Apparent and true polar wander and the geometry of the geomagnetic field over the last $200 \mathrm{Myr}, J$. Geophys. Res., 107(B11), 2300, doi:10.1029/2000JB000050.

Bevis, M., E. Kendrick, R. Smalley Jr., B. Brooks, R. Allmendinger, and B. Isacks (2001), On the strength of interplate coupling and the rate of back arc convergence in the central Andes: An analysis of the interseismic velocity field, Geochem. Geophys. Geosyst., 2(11), doi:10.1029/ 2001GC000198.

Butler, R., D. Richards, T. Sempere, and L. Marshall (1995), Paleomagnetic determinations of vertical-axis rotations from Late Cretaceous and Palaeocene strata of Bolivia, Geology, 23, 799-802.

Cande, S. C., and D. V. Kent (1995), Revised calibration of the geomagnetic polarity timescale for the late Cretaceous and Cenozoic, J. Geophys. Res., 100, 6093-6096.

Cladouhos, T. T., R. W. Allmendinger, B. Coira, and E. Farrar (1994), Late Cenozoic deformation in the central Andes: Fault kinematics from the northern Puna, northwest Argentina and southwest Bolivia, J. S. Am. Earth Sci., 7, 209-228.

Demerest, H. H. (1983), Error analysis for the determination of tectonic rotation from paleomagnetic data, J. Geophys. Res., 88, $4321-$ 4328.

DeMets, C., R. G. Gordon, D. F. Argus, and S. Stein (1994), Effect of recent revisions of the geomagnetic time scale on estimates of current plate motions, Geophys. Res. Lett., 21, 2191-2194.

Dunn, J. F., K. G. Hartshorn, and P. W. Hartshorn (1995), Structural styles and hydrocarbon potential of the Sub-Andean thrust belt of southern Bolivia, in Petroleum Basins of South America, AAPG Mem., 62, $523-$ 543.

Echavarria, L., R. Hernandez, R. Allmendinger, and J. Reynolds (2003), Subandean thrust and fold belt of northwestern Argentina: Geometry and timing of the Andean evolution, AAPG Bull., 87, 965-985.

Evernden, J. F., S. J. Kriz, and C. M. Cherroni (1977), Potassium-argon ages of some Bolivian rocks, Econ. Geol., 72, 1042-1061.

Fisher, R. A. (1953), Dispersion on a sphere, Proc. R. Soc. London, 217, 295-305.

Funning, G. J., R. M. D. Barke, S. H. Lamb, E. Minaya, B. Parsons, and T. J. Wright (2005), The 1998 Aiquile Bolivia earthquake: A seismically active fault revealed with InSAR, Earth Planet. Sci. Lett., 232, $39-49$.

Gilder, S., S. Rousse, D. Farber, B. McNulty, T. Sempere, V. Torres, and O. Palacios (2003), Post-middle Oligocene origin of paleomagnetic rotations in Upper Permian to Lower Jurassic rocks from northern and southern Peru, Earth Planet. Sci. Lett., 210, 233-248.

Grant, J. N., C. Halls, W. Avila, and N. J. Snelling (1979), K-Ar ages of igneous rocks and mineralisation in part of the Bolivian tin belt, Econ. Geol., 74, 838-851.
Gubbels, T. L., B. L. Isacks, and E. Farrar (1993), High-level surfaces, plateau uplift, and foreland development, Bolivian central Andes, Geology, 21, 695-698.

Hartley, A. F., P. Turner, G. Williams, and S. Flint (1988), Palaeomagnetism of the Cordillera de la Costa, northern Chile: Evidence for local forearc rotation, Earth Planet. Sci. Lett., 89, 375-386.

Heki, K., Y. Hamano, M. Kono, and T. Ui (1985), Palaeomagnetism of Neogene Ocros dyke swarm, the Peruvian Andes: Implication for the Bolivian orocline, Geophys. J. R. Astron. Soc., 80, 527-534.

Herail, G., P. Soler, M. Bonhomme, and J. L. Lizeca (1993), Evolution geodynamique de la transition entre l'Altiplano et al Cordillere Orientale au Nord d'Oruro (Bolivie): Implications sur le deroulement de l'orogenese andine, C. R. Acad. Sci., 317, 515-522.

Hoffman, K. A., and R. Day (1978), Separation of multi-component NRM: A general method, Earth Planet. Sci. Lett., 40, 433-438.

Hoke, L., D. Hilton, S. H. Lamb, K. Hammerschmidt, and H. Friedrichsen (1994), ${ }^{3} \mathrm{He}$ evidence for a wide zone of active mantle melting beneath the central Andes, Earth Planet. Sci. Lett., 128, 341-355.

Isacks, B. (1988), Uplift of the Central Andean Plateau and bending of the Bolivian Orocline, J. Geophys. Res., 93, 3211-3231.

Jordan, T. E., J. H. Reynolds III, and J. P. Erikson (1997), Variability in age of initial shortening and uplift in the central Andes, $16-33^{\circ} 30^{\prime} \mathrm{S}$, in Tectonic Uplift And Climate Change, edited by W. Ruddiman, pp. 4161, Springer, New York.

Kennan, L. (1994), Cenozoic tectonics of the central Bolivian Andes, Ph.D. thesis, Dep. of Earth Sci. Univ. of Oxford, Oxford, U.K.

Kennan, L., S. H. Lamb, and C. Rundle (1995), K-Ar dates from the Altiplano and Cordillera Oriental of Bolivia: Implications for Cenozoic stratigraphy and tectonics, J. S. Am. Earth Sci., 8, 163-186.

Kennan, L., S. H. Lamb, and L. Hoke (1997), High-altitude palaeosurfaces in the Bolivian Andes: Evidence for late Cenozoic surface uplift, Geol. Soc. Spec. Publ., 120, 307-323.

Kirschvink, J. L. (1980), The least-squares line and plane and the analysis of palaeomagnetic data, Geophys. J. R. Astron. Soc., 62, 699718.

Kono, M., K. Heki, and Y. Hamono (1985), Paleomagnetic study of the central Andes: Counterclockwise rotation of the Peruvian block, J. Geodyn., 2, 193-209.

Lamb, S. H. (2000), Active deformation in the Bolivian Andes, South America, J. Geophys. Res., 105, 25,627-25,653.

Lamb, S. H. (2001a), Vertical axis rotations in the Bolivian orocline, South America: 1. Paleomagnetic analysis of Cretaceous and Cenozoic rocks, J. Geophys. Res., 106, 26,605-26,632.

Lamb, S. H. (2001b), Vertical axis rotations in the Bolivian Orocline, South America: 2. Kinematic and dynamical implications, J. Geophys. Res., $106,26,605-26,632$.

Lamb, S. H., and L. Hoke (1997), Origin of the high plateau in the central Andes, Bolivia, South America, Tectonics, 16, 264-623.

Lamb, S. H., and D. E. Randall (2001), Deriving palaeomagnetic poles from independently assessed inclination and declination data: Implications for South America poles since 120 Ma, Geophys. J. Int., 146, 349370 .

Lamb, S. H., L. Hoke, L. Kennan, and J. Dewey (1997), The Cenozoic evolution of the central Andes in Bolivia and northern Chile, Geol. Soc. Spec. Publ., 121, 237-264.

MacFadden, B. J., F. Anaya, H. Perez, C. W. Naeser, P. K. Zeitler, and K. E. Campbell (1990), Late Cenozoic paleomagnetism and chronology of Andean basins of Bolivia: Evidence for possible oroclinal bending, J. Geol., 98, 541-555.

MacFadden, B. J., F. Anaya, and J. Argollo (1993), Magnetic polarity stratigraphy of Inchasi: A Pliocene mammal-bearing locality from the Bolivian Andes deposited just before the Great American Interchange, Earth Planet. Sci. Lett., 114, 229-241.

MacFadden, B. J., F. Anaya, and C. C. Swisher III (1995), Neogene paleomagnetism and oroclinal bending of the central Andes of Bolivia, J. Geophys. Res., 100, 8153-8167.

McFadden, P. L., and M. W. McElhinny (1988), The combined analysis of remagnetization circles and direct observations and direct observations in palaeomagnetism, Earth Planet. Sci. Lett., 87, 161-172.

McQuarrie, N. (2002), The kinematic history of the central Andean foldthrust belt, Bolivia: Implications for building a high plateau, Geol. Soc. Am. Bull., 114, 950-963.

Menke, W. (1988), Geophysical Data Analysis: Discrete Inverse Theory, Int. Geophys. Ser, vol. 45, Elsevier, New York.

Mingramm, A., A. Russo, A. Pozzo, and L. Cazau (1979), Serras Subandinas, Segundo Simp. Geol. Reg. Argent., 1, 95-138.

Myers, S. C., S. Beck, G. Zandt, and T. Wallace (1998), Lithospheric-scale structure across the Bolivian Andes from tomographic images of velocity and attenuation for $\mathrm{P}$ and $\mathrm{S}$ waves, J. Geophys. Res., 103, 21,23321,252 . 
Prezzi, C. B., and R. N. Alonso (2002), New paleomagnetic data from the northern Argentine Puna: Central Andes rotation pattern reanalyzed, J. Geophys. Res., 107(B2), 2041, doi:10.1029/2001JB000225.

Redwood, S., and R. MacIntyre (1989), K-Ar dating of Miocene magmatism and related epithermal mineralization of the northeastern Altiplano of Bolivia, Econ. Geol., 84, 618-630.

Richards, D. R., R. F. Butler, and T. Sempere (2004), Vertical-axis rotations determined from paleomagnetism of Mesozoic and Cenozoic strata of the Bolivian Andes, J. Geophys. Res., 109, B07104, doi:10.1029/ 2004JB002977.

Roperch, P., and G. Carlier (1992), Paleomagnetism of Mesozoic rocks from the central Andes of southern Peru: Importance of rotations in the development of the Bolivian orocline, J. Geophys. Res., 97, 17,23317,249 .

Roperch, P., G. Herail, and M. Fornari (1999), Magnetostratigraphy of the Miocene Corque basin, Bolivia: Implications for the geodynamic evolution of the Altiplano during the late Tertiary, J. Geophys. Res., 104, 20,415-20,429.

Roperch, P., M. Fornari, G. Herail, and G. V. Parraguez (2000), Tectonic rotations within the Bolivian Altiplano: Implications for the geodynamic evolution of the central Andes during the late Tertiary, J. Geophys. Res., $105,795-820$.

Rousse, S., S. Gilder, D. Farber, B. McNulty, and V. R. Torres (2002), Paleomagnetic evidence for rapid vertical-axis rotation in the Peruvian Cordillera ca.8 Ma, Geology, 30, 75-78.

Rousse, S., S. Gilder, M. Fornari, and T. Sempere (2005), Insight into the Neogene tectonic history of the northern Bolivian Orocline from new paleomagnetic and geochronologic data, Tectonics, 24, TC6007, doi:10.1029/2004TC001760.

Scanlan, P. M., and P. Turner (1992), Structural constraints on palaeomagnetic rotations south of the Arica bend, northern Chile: Implications for the Bolivian Orocline, Tectonophysics, 204, 141-154.

Schmidtz, M., and J. Kley (1997), The geometry of the central Andean back arc crust: Joint interpretation of cross-section balancing and seismic refraction data, J. S. Am. Earth Sci., 10, 99-110.
Schneider, A. (1985), Eruptive processes, mineralisation and isotopic evolution of the Los Frailes- KariKari region, Bolivia, Ph.D. thesis, Imp. Coll., London.

Servicio Geologico de Bolivia and SGAB International Suecia (1992), Carta geologica de Bolivia, Hoja Uncia, sheet 6238, scale 1:100,000, Publ. SGB Ser. 1-CGB-15, La Paz.

Servicio Geologico de Bolivia and SGAB International Suecia (1993), Carta geologica de Bolivia, Hoja Huanuni, sheet 6239, scale 1:100,000, Publ. SGB Ser. 1-CGB-15, La Paz.

Sheffels, B. (1990), Lower bound on the amount of crustal shortening in the central Bolivian Andes, Geology, 18, 812-815.

Somoza, R. (1994), South American reference pole for the mid-Cretaceous: Further constraints in the interpretation of Andean palaeomagnetic data, Geology, 22, 933-936.

Somoza, R., S. Singer, and A. Tomlinson (1999), Paleomagnetic study of upper Miocene rocks from northern Chile: Implications for the origin of late Miocene-Recent tectonic rotations in the southern central Andes, J. Geophys. Res., 104, 22,923-22,936.

Uba, C. E., C. Heubeck, and C. Hulka (2005), Facies analysis and basin architecture of the Neogene Subandean synorogenic wedge, southern Bolivia, Sediment. Geol., 180, 91-123.

Watts, A. B., S. H. Lamb, J. D. Fairhead, and J. F. Dewey (1995), Lithospheric flexure and bending of the central Andes, Earth Planet. Sci. Lett., $134,9-21$.

Zijderveld, J. D. A. (1967), AC demagnetisation of rocks: Analysis of results, in Methods in Paleomagnetism, edited by D. W. Collinson, K. M. Creer, and S. K. Runcorn, pp. 245-286, Elsevier, New York.

R. Barke, ExxonMobil, Union Row, Aberdeen AB10 1SA, UK (richard.barke@exxonmobil.com)

S. Lamb and C. MacNiocaill, Department of Earth Sciences, Parks Road, Oxford, OX1 3PR, UK. (simon.lamb@earth.ox.ac.uk; conall.macniocaill@ earth.ox.ac.uk) 